\title{
Studies on Dharmakīti's religious philosophy (3): Compassion and its role in the general structure of PV 2
}

\author{
Vincent Eltschinger, Vienna
}

\author{
Translated from the French by \\ Raynald Prévèreau
}

\section{Introduction}

1.1. The focus of the present study is PV 2.120-131ab (\$2). In those verses, Dharmakīti attempts to prove, against a Mīmāmsaka opponent, that compassion, ${ }^{1}$ when practiced constantly over a myriad of successive lifetimes, is liable to increase gradually until it may become the very essence of a given mental series.

That argument largely rests on the belief in compassion's "spontaneity" (svarasavāhitva, etc.), a notion that itself cannot be fully understood without appealing to the Mahāyāna dogma of the three "objects" of immeasurable (apramāna) sentiments. Since I contend that understanding that doctrinal theme, especially in its ANS formulation, is essential to grasping the full meaning of PV 2.120-131ab, I will here take up a detailed exegesis of the ANS, the BoBh, the MSA(Bh) and their explanation by Sthiramati (\$4). Contrary to Takashi Iwata, I tend to believe that Dharmakirti did not commit himself on the causes and conditions that lead to the initial impulse toward the constant practice (abhyāsa, bhāvanā) of compassion. This was also Devendrabuddhi's and Sākyabuddhi's understanding, both of whom, by resorting to the traditional themes of gotra and kalyānamitra (§3), remind the exegete of another Mahāyāna doctrinal complex that was well in favour in Idealist sources.

1.2. In contrast to Dignāga, ${ }^{2}$ Dharmakīrti shows a constant concern for grounding logic and

\footnotetext{
${ }^{1}$ On compassion in Dharmakīti, see Inami 1986, Dunne 1996, Franco 1997: 4-8, Iwata 2011. The research for this paper was made possible through the generous support of the Swiss National Research Fund. Financial support for its English translation was provided by the Fonds Elisabet de Boer (Lausanne). I wish to thank T. Iwata for having put the manuscript of his study at my disposal.

${ }^{2}$ PV 2 is Dharmakirti's exhaustive commentary on the benedictory verse (maingalaśloka) of PS. In that verse, Dignāga attributes five properties to the Blessed Buddha (or rather: describes him by means of five properties): the Blessed One is (has become and is similar to?) a means of valid cognition (pramānabhüta); he strives for the good of the world (jagaddhitaisin); he is the teacher (śästr), the sugata, the protector (tāyin) of living beings. In his own commentary (PSV) to this verse, Dignāga subsumes the last four properties/epithets under
} 
epistemology in reality. This is the case for his theories of language and universals, perception and reasoning. Even what falls under buddhology is not an exception. But in order to secure the validity of Dignāga's inference regarding the Buddha's authority as a source of knowledge, Dharmakirti had to explain the properties/epithets introduced by his predecessor in terms of a network of causal relations that would allow logical "retrogression." From the outset, that epistemological necessity led Dharmakīrti into a "narrativization" of the fourfold structure inherited from Dignāga. For as is obvious, every causal sequence implies a process in time. And when it comes to buddhology, a chronological sequence generally coincides with a narrative or "biographical" sequence. We could therefore reasonably expect that Dharmakīti would appeal to the more or less standardized descriptions of a Bodhisattva's career, i.e., to a set of narrative sequences that would be recognizable both doctrinally and textually. These sequences provide Dharmakīrti with the model for a unilinear causal process in the form of a narrative where both norm and mythology are intertwined. The categories inherited from Dignāga then serve to mark the sequence or periods of that process. Such periodization, however, does not always fit perfectly with the standard descriptions of a Bodhisattva's career. In other words, in Dharmakīrti the fourfold structure inherited from Dignāga is superimposed on a complex series of narrative micro-sequences that are always doctrinally recognizable. And the true basis for the causal relations introduced among those properties/epithets is to be found in the concatenation of these micro-sequences. At the end of this paper, I will take up one of those narrative microsequences, namely, the micro-sequence of (conventional) bodhicittotpāda and its concomitant pranidhāna (\$5). For that notion seems to me capable of explaining why the property of striving for the good of the world, that is to say the property of being moved by compassion, is the direct cause of the property of being the Teacher, and the indirect cause of the very authority (prāmānya) of the Buddha in salvational matters.

\section{The systematics of karuña}

2.1. At PV 2.34b-119, Dharmakīrti presents his arguments in favour of rebirth. In his PVP to PV 2.119, Devendrabuddhi summarizes the position as follows: "In this way, the [uninterrupted] series of births and deaths is established; hence the constant practice (abhyāsa) of mental qualities such as compassion is [made possible over these successive lifetimes], and there is no incompatibility in [the claim that those mental qualities] become the essence [of a mental series] if [their] practice is extreme[ly intense]." Then follow two formal arguments (prayoga) using a svabhāvahetu as evidence and taking great compassion (mahākarunāa) as their subject. In the first case, the evidence, "being a mental quality" (manoguna), is said to

abhidharmic categories: the Blessed One is (has become and is similar to?) a means of valid cognition because he is possessed with the double perfection of cause $\left(\right.$ het ${ }^{\circ}$ ) and effect (phalasampad). Here, "perfection of cause" refers to the double perfection of intention $\left(\bar{a} s a y a^{\circ}\right)$ and praxis (prayogasampad), while "perfection of effect" refers to the double perfection of one's own good (svārth $a^{\circ}$ ) and the good of others (parārthasampad). These four sub-perfections therefore correspond to properties/epithets 2 to 5 of PS: ásayasampad corresponds to jagaddhitaișitva, prayogasampad corresponds to sāstrttva, svārthasampad corresponds to sugatatva, and parārthasampad corresponds to tāyitva. See $§ 5$ below.

${ }^{3}$ PVP D51b4-5/P58a8-b1: de ltar na / skye ba dang 'chi ba'i rgyun grub pa de ltar na snying rje la sogs pa'i yid kyi yon tan rnams goms pa yod pa dang / shin tu goms pa yod pa na de'i bdag nyid du gyur pa 'gal ba yod pa ma yin no //. Note also PVV 53,13-14: tad evam ... dehanivrittāv api janmaparamparāsambhave yuktah krpābhyāsa ity abhyāsāt seti samarthitam /. 
imply the property to be proven, namely, "to become the entire essence of man if its practice is extreme[ly intense]." In the second case, the property of "being a mental quality that [always] improves with constant practice" is said to imply the property of "gradually becoming the essence of man as a result of an extreme[ly intense] practice." This then is broadly the doctrine that Dharmakīrti will attempt to establish at PV 2.120-131ab: as a result of a constant practice over a myriad of successive lifetimes, the mental quality of compassion gradually forms the very essence of the mental series, to the detriment of opposing mental events (dharma).

2.2. It should be noted at this point that compassion is defined in the Buddhist tradition in terms of its intention (bzhed $p a)$, object $(y u l=v i s a y a)$, aspect $($ rnam pa $=\bar{a} k \bar{a} r a)$ and nature (rang bzhin/rang gi ngo bo = svabhāva/svarüpa $).{ }^{5}$ (1) Disinterested action guides the compassionate being: "[compassion] does not rest on the [expectation] of a benefit in return (pratyupakāra), or on [reputation and honour];" it consists in acting with the sole good of others (parārtha) in mind. ${ }^{6}$ (2) Compassion is "equality toward all beings" (sarvasattveșu samatā): it is directed toward the totality of beings living on the three planes of existence (tridhâtu) since it is free of attachment toward friends and free of hostility toward enemies. ${ }^{7}$ (3) Compassion "has as its aspect the desire that [beings] be entirely liberated from the suffering [that afflicts them]" (*atyantaduhkhaviyogecchākāra) so that suffering acquires the property of being unable to reappear (*apunarutpattidharma). ${ }^{8}$ (4) Finally, the nature of compassion is the "absence of hatred" (adveșa). ${ }^{9}$

${ }^{4}$ See PVP D51b5-7/P58b1-5 (with the example of a śrotriya who has become a kāpālika), together with PVT Nye D116a4/P142a2 and PVT Nye D116a5/P142a2-3.

${ }^{5}$ Note PVT Nye D88a7/P107b4-5: thugs rje* yang ci zhig bzhed pa na'am / gang la'am / rnam pa** gang gis sam / ci'i rang bzhin can du 'jug par 'gyur zhe na / *P rjes; **P par. See also PVT Nye D88b1-2/P107b6-8 and, for references to this type of classification, Iwata 2011:213-214, note 9; the rubrics svabhāva, $\bar{a} k \bar{a} r a$ and ălambana are found in AKBh 415,7-8 ad AK 7.33d.

${ }^{6}$ PVP D16a3-4/P18a1: phan btags pa'i lan la sogs pa la ltos pa med pa can ... PVT Nye D88b1-2/P107b5-7: phan gdags pa byas pa dag las* rnyed pa thob pa ni phan btags** pa'i lan no // sogs pa'i sgras ni grags pa dang bsnyen bkur la sogs pa bzung ngo // ... sems can gyi don nyid bzhed pa na 'jug par 'gyur ro zhes bya ba' $i$ don to //*P la; **D gdags. pratyupakāra at PVA 107,5; see also MSA(Bh) 17.58.

${ }^{7}$ PVP D16a4/P18a1: sems can thams cad la snyoms pa ... Śākyabuddhi's explanation at PVṬ Nye D88b2/ P107b7 goes as follows: mdza' po dang dgra po dag la rjes su chags pa dang khong khro ba mi mnga' ba'i phyir / khams gsum gyi khongs su gtogs pa'i sems can thams cad la snyoms pa'o //. I find problematic the claim that compassion is equality toward all beings. Indeed, as is suggested in the commentaries of Devendrabuddhi and Śākyabuddhi, the compassion that is here defined has not been practiced yet (PVT Nye D88b3/P108a1: ji ltar de nyid goms pa yin zhe na /. "The [compassion that we just defined], how do we come to practice it?"). Now, in the Vaibhāṣika Abhidharma, while equality is a characteristic of the great compassion (mahākarunāa) of Buddhas and great Bodhisattvas, it is not so for ordinary compassion (karunā; on the notion of "great compassion," see $\S 4.3$ below). At AK 7.33d it is asked (AKBh 415,5: karunāmahäkarunayoh kị̣ nānākaranam /): "What is the difference between compassion and great compassion?" Referring to the third difference, Vasubandhu answers (AKBh 415,7-8: ālambanata ekatridhātvālambanatvāt /): "[Their] object, since [whereas compassion] is only directed toward one [plane of existence, great compassion is directed] toward [all] three planes of existence." Take note also of AKBh 415,3 ad AK 7.33bc, where gocara is explained as a alambanena traidhātukālambanāt, and samatva as samatvena sarvasattveșu samavrttitvāt. Śākyabuddhi himself noted that sarvasattveșu samatā defines great compassion and not ordinary compassion (PVT Nye D88b2/P107b7-8: 'dis $n i^{*}$ yul chen po can nyid du bstan pa'i phyir thugs rje chen po bshad do // *D omits ni).

${ }^{8}$ PVP D16a4/P18a1-2: shin tu sdug bsngal dang bral bar 'dod pa'i rnam pa can ... Explained as follows by 
2.3. At PV 2.120ad 1 , an opponent comes in who believes that the two prayogas mentioned above (\$2.1) are inconclusive (anaikāntika). The opponent objects: ${ }^{10}$

[Objection:] Even though [compassion can be] improved (viśeșa) [slightly] through constant practice, nature (svabhāva) [still] cannot be transgressed, as is examplified by jumping or heating water.

According to Devendrabuddhi, this svabhāvātikrama consists in "freeing [oneself] from [compassion's] opposing (vipakșa) [dharmas];" according to Manorathanandin, it consists in "going beyond the property, belonging to [mental qualities] such as compassion, of [always] being mixed with their opposing [dharmas]."11 Transgressing nature, in the case of a given mental series, would therefore mean " ${ }^{12}$ "to consist [entirely] in [a mental quality] such as compassion, [a compassion that is] not mixed with its opposing [dharmas] and emerges spontaneously (svarasena)."

We learn from Śākyabuddhi that the opponent introduced at PV 2.120ad ${ }_{1}$ is none other than the Mīmāmsaka doctor, Kumārila, of whom he quotes one verse. The verse in question reads as follows: "'[A person] may well jump as far as ten cubits (hasta) in the air; [nonetheless,]

Śākyabuddhi at PVṬ Nye D88b3/P107b8: de yang mi skye ba'i chos can nyid yin pa'i phyir ... See MSABh 121,21: karun̄ā duhkhaviyogākārā, and more importantly MSAVBh D55b4-5/P65b5: snying rje ni sdug bsngal dang bral bar 'dod pa'i rnam pa yin pas sems can rnams sdug bsngal dang bral bar gyur cig ces dmigs pa'i phyir ro //. See also PVA 53,11; 53,12; 53,15. According to the Sarvāstivādin-Vaibhāṣika Abhidharma and Mahāyānist sources, only great compassion is possessed with a real salvational efficiency: "[1]a karuṇa , simple sentiment de commisération, ne protège pas les êtres; la mahākarunā est une compassion efficace et protège les êtres de la terreur du Saṃsāra" (Traité III.1707). See in general Traité III.1705-1710, and AKBh 415,10 ad AK 7.33d (seventh difference between karuñā and mahākaruñā [aparitrānaparitrānatah /]: "La pitié ne protège pas, la grande pitié protège" [Kośa 7.79]). Compassion is thus defined here as a desire rather than as the salvational act itself.

9 PVP D16a4/P18a2: zhe sdang med pa ... Note also AKBh 415,7: svabhāvato 'dveșāmohasvabhāvatvāt/. "[Compassion and great compassion differ firstly] in nature, since [whereas] the nature of [compassion] is the absence of hatred, [the nature of great compassion] is the absence of bewilderment."

${ }^{10}$ PV 2.120ad ${ }_{1}$ : abhyāsena viśeșe 'pi lañghanodakatāpavat / svabhāvātikramo mā bhūd iti cet ... For the inconclusiveness of the two prayogas, see PVP D51b7-52a1/P58b5.

11 PVP D52a1/P58b5-6: rigs mi mthun pa las 'das pa; PVV 53,17-18: krpādes tadvipakșasañkīrnatvasyātikramah.

12 PVV 53,18: vipakṣāvyavakīrṇasvarasapravṛttakṛāadimayatā sātmībhāvaḥ. Cf. PVP D52a1/P58b6: rang gi ngang gis 'jug pa'i mtshan nyid can snying rje la sogs pa'i bdag nyid du 'gyur ba.

${ }^{13}$ PVT Nye D116a5-6/P142a4-5: de skad du gZhon nu ma len gyis / mkha' la dom bcu tshun chad du // mchongs nas 'gro ba zhes bya gang // des ni lan brgyar goms na yang // rgyang grags brgyar ni mchong mi nus // zhes smras pa yin no //. TS no. $3168 \approx \mathrm{R} 9,16-17$ (where the verse is explicitly ascribed to the BT): daśahastāntarạ vyomno yo nāmotplutya gacchati / na yojanam asau gantum śakto 'bhyāsaśatair api //. Kamalaśīla's explanation at TSP K826,25-27 ad TS no. 3168/S1000,17-20 ad TS no. 3167 goes as follows: yadi nāma kecid upacitaśleșmavapuṣo hastamātravyomotplavanāsamarthāh paścād abhyāsakrameṇa samāsāditagātralāghavā daśahastāntaragaganavilànghano (sic) jātāh, tathāpi na te yojanam ekam api khagapatham utpatitum samarthāh prayatnaśatenāpi bhavanti /. "Some [people] whose body abounds in phlegm cannot even jump a single cubit in the air; [now,] it is quite possible that due to a series of exercises, having regained the lightness of their bodies, they then start jumping up to ten cubits in the air; [but] even thus, a hundred attempts would not suffice for them to reach an upward distance of one yojana." It is clear from TS no. 3169 that the real target of this verse was not compassion, but rather jūanna/prajñā, which leads to omniscience when perfected. According to Decourtemanche (1911: 376), the hasta ("average cubit") is a unit of length equivalent to 0.4794 metres; the distance measurements are easily obtained from the cubit: a krośa is equivalent to 3835.2 metres, while a 
hundreds of repetitions will not suffice to enable him to reach [the distance of] one yojana." Now if we are to accept the portrayal proposed by Dharmakīrti and his successors, Kumārila here did not deny compassion or its quality as a psychological event. Rather, Kumārila objected to the claim that such mental qualities have the potential to increase through constant practice up to the point where, at the very end of their developing process (atyantaprakarsanișthām gacchanti, etc.), ${ }^{14}$ they may form the essence (sātmībhāva, etc.) of the human psyche. The development of these mental qualities, argued Kumārila, is strictly limited (vyavasthitotkarșa, etc.). ${ }^{15}$

Of the two examples provided by Dharmakīrti to illustrate Kumārila's position, namely, jumping and heating water, the first is supposed to refute the claim that constant practice leads to continuous improvement of the competence in question: "When jumping, a person very well trained at jumping may cover (gnon par byed pa) a certain distance, but not more; [i.e., he does not jump] one yojana, half a krośa or even one krośa." The second example is meant to show that even if we admitted the possibility of a constant increase on the level of the cause, the result would still be finite due precisely to the finite nature of the substratum (ásraya): ${ }^{17}$ "Even when heated [very] intensely, water does not turn into fire, even after a long time[, since it will have evaporated completely in the meantime]." Manorathanandin therefore concludes as follows his explanation of the Mīmāmsaka objection: ${ }^{18}$ "Just as there is only a [slight] difference [compared to] the naturally fixed (prakrtisiddha) [limit of] jump and temperature, so too there is only a [slight] increase [of compassion] but [the mental series] does not become coessential with compassion." Unless a transgression of ordinary psychological structure is possible, Dharmakīrti's argument must be rejected as inconclusive. ${ }^{19}$

yojana is equivalent to 15340.8 metres.

${ }^{14}$ Atyantaprakarșaniștha at PVA 105,32; paraprakarșanișthā at PVA 106,27; prakarșanișthām ... gacchet at PVV 54,5; prakarșanișthām gacchanti at PVV 55,28; de'i bdag nyid du gyur pa'i thugs rje gang yin pa de 'dra ba mthar phyin pa ldog pa med par 'gyur ro at PVP D16a6-7/P18a5 (PVT Nye D89a1/P108a8: mthar phyin pa ni 'phel ba'i mthar phyin pa'o); shin tu 'phel ba'i chos can at PVP D53b1/P60b4; see also note 34 below.

${ }^{15}$ Vyavasthitotkarșabhāgin at PVA 106,8; vyavasthitotkarșatā at PVA 106,11, 106,13, 107,3, PVV 54,15-16, 55,14, 55,19; vyavasthitotkarșa at PVA 106,14; rnam par gnas pa nyid 'phel bar 'gyur ro at PVP D52a6/P59a4; rnam par gnas pa 'phel ba can at PVP D52a7/P59a5; khyad par du rnam par gnas pa can at PVP D53a7/P60b3; 'phel ba tshad nges pa can at PVT Nye D116b3/P142b2, D116b4/P142b4, PVP D53b1/P60b4.

${ }^{16}$ PVP D52a2/P58b6-7: mchongs bzhin te / dper na shin tu legs par goms par byas pa can gyi skyes bu mchongs pa na / yul cung zad cig gnon par byed kyi / dpag tshad dam rgyang grags phyed dam / rgyang grags sam lhag pa ma yin pa lta bu'o //. See also PVT Nye D116a5/P142a3-4, and note PVV 53,21: na hi puruso 'tyartham lañghane krtābhyāso yojanam ardhayojanam vā lanighayati /.

${ }^{17}$ PVP D52a2-3/P58b6-7: chu'i dro ba bzhin du ste chu'i dro ba ches shin tu gyur pa na yang dus yun ring po nas kyang 'bar ba nyid du mi 'gyur ba lta bu'o //. Note also PVV 53,21-22: nāpy udakam ekāntam tāpyamānam dahanībhavati; PVP D52a5/P59a3-4: dper na chu'i dro ba nyid thob par byung ba'i rang bzhin zad pa nyid lta bu'o; PVV 54,3-4: udakatāpavat / kvāthyamānam hy udakam kșīyata evety asthirāśrayah; Vibh. 54, note 1: na jvalati /.

${ }^{18}$ PVV 53,22-24: prakrtisiddhāl langhanāt sparśāc ca viśeșamātram bhavati yathā / tathotkarșamātram syāt krpayā na tu sätmībhäva iti cet /.

${ }^{19}$ PVP D52a3/P58b8: de ltar na rang bzhin las mi 'das pa'i phyir ma nges pa yin no zhe na /. 
2.4. In his reply, Dharmakīrti begins by shedding some light on the specific properties of jumping; an explanation in which he has no choice but to concede to Kumārila the validity of his description. But in so doing, Dharmakirti spells out the two conditions that compassion would have to meet, in contrast to jumping and heating water, for its maximum increase to be possible, and for his argument to be conclusive: ${ }^{20}$

\begin{abstract}
If the [improvement that has been] produced [by the constant practice of compassion] required, [as is the case for jumping,] a further effort [to come again into existence], and if its substratum were unstable [as is the case for water, then] the improvement could not increase [by much]. Now a nature is not like that[, i.e., it does not fail to proceed spontaneously]. [The growth of that which requires a further effort to come again into existence is strictly limited] because the factors (sädhana) whose power is occupied with [recreating] the [previous improvement] are [ipso facto] incapable (asāmarthya) [of adding a supplementary property] to subsequent improvements, and because its substratum does not last indefinitely (nityam). [Therefore,] because the improvement, even when it is [slightly] increased, is not natural[, it requires a further effort to be recreated]. [But] if it were the case that an [improvement] that has been produced did not depend on a further effort (punaryatna) [to come again into existence], then any new effort (yatno 'nyah) could produce a [new] improvement (viśesakrt).
\end{abstract}

The improvement (viśeșa, phul du byung ba=atiśaya) that is peculiar to jumping requires a further effort (punaryatnāpekșā, etc.) to come again into existence "once [the factor, i.e., the effort,] that brought [it into existence] has ceased (ädhāyakanivrttau)." 21 Now, according to Devendrabuddhi, "the growth of any improvement that requires a [further] effort in order to be produced anew is [strictly] limited (vyavasthitotkarsa);" or, to use an equivalent formulation by Manorathanandin, ${ }^{23}$ "to have a limited growth implies depending on a further effort [and] having an unstable substratum." Moreover, that improvement ${ }^{24}$ "is not at all a svabhāva, [i.e.,] prakrti, since the existence and cessation of the [said] improvement depend on the presence and absence of [its] cause[, i.e., of the effort by which it is produced]." Indeed, a nature, like space for example, does not depend on anything other than itself, but proceeds spontaneously (svarasavāhin). ${ }^{25}$

${ }^{20}$ PVP D52a3-4/P58b8-59a1: gal te de byas na yang zhes bya ba la sogs pas khyad par dang bcas pa'i gtan tshigs bstan pa'i sgo nas ma nges pa'i lan 'debs par byed do //. PV 2.120d $2-123$ : ăhitah sa cet // punaryatnam apekșeta yadi syāc cāsthirāśrayah / viśeșo naiva vardheta svabhāvaś ca na tādṛ́śh // tatropayuktaśaktīnām viśeșān uttarān prati / sādhanānām asāmarthyān nityam cānāśrayasthiteh // viśsșasyāsvabhāvatvād vṛddhāo apy āhito yadā / nāpekșeta punaryatnam yatno 'nyah syäd viśeșakrt //. My interpretation of $\mathrm{PV} 2.120 \mathrm{~d}_{2}-123$ is based on PVP D52a6-b1/P59a4-8.

${ }^{21}$ PVV 54,1-2: ādhāyakanivrttāe ātmalābhāya punaryatnam apekșeta. Note also PVP D52a4/P59a2: yang bya ba'i phyir 'bad rtsol la yang ltos yin te; PVP D52b2/P59b1: 'jug pa'i phyir yang 'bad rtsol la ltos ...; PVP D52a6-7/P59a5: yang bya ba'i phyir 'bad rtsol la ltos pa; PVV 54,17: apekseta punaryatnam ... àtmano lābhāya; PVV 54,2-3: punaryatnāpekșayaiva pravartate. Note also PVP D52b1-2/P59a8-b1: 'bad rtsol gyis bsgrub par bya ba yin te.

${ }^{22}$ PVP D52a6-7/P59a5: gang zhig yang bya ba'i phyir 'bad rtsol la ltos pa ... phul du byung ba rnam par gnas pa 'phel ba can ...

${ }^{23}$ PVV 54,15-16: punaryatnāpekșitvenāsthirāśrayatvena vyavasthitotkarșatā vyāptā.

${ }^{24}$ PVV 54,5-6: naiva svabhāvah prakrtih ... < <iśesasya ${ }_{\mathrm{Vibh} .54, \text { note } 4}>$ hetusannidhānavyavadhānasāpekșatvāt pravrttinivrttyoh /. PVA 106,18-19: tathāpi tasya na svabhāvatāa / na hi hetusannidhānatāpekși svabhāvo yuktah /.

${ }^{25}$ Svarasavāhin at PVV 54,2-4, 54,17, 55,1, 55,3, 55,6; PVA 106,19, 106,24, 106,28, 106,29; svarasapravrttakrpādimayatā at PVV 53,18; rang gi ngang gis 'jug pa(/'gyur ba) at PVP D52a4-5/P59a2-3, D52b1/P59a7-8, D54a7-b1/P61b7-8 and passim; PVT Nye D116a7/P142a5; D116b1/P142a8; D116b6/P142b6. "Like space" according to Vibh. 54, note 2: langhanaviśeșavan na prakṛtih / anyānapekṣatvāt svabhāvasyākāśavat /. 
2.5. Let us now consider how a mental quality such as compassion meets this general condition when constantly practiced. Devendrabuddhi introduces the next verse as follows: ${ }^{26}$

At a given moment, when one has reached a distinctive practice (prayoga) of [mental qualities] such as compassion, [these qualities] no longer depend on a new practice to proceed, but [rather], the acquisition of [each new] improvement proceeds without [any] effort.

Once the practice or cultivation of the mental quality has been developed, its progress no longer follows the model of jumping, but rather that of wood when put in the presence of fire, that of mercury transmuted through diverse alchemical operations, or that of base gold that we refine: $:^{27}$

[Mental qualities] of the likes of compassion[, joy and equanimity], which arise as a result of constant practice, proceed spontaneously in the mind, just as wood, mercury or gold [change spontaneously] due to fire[, to alchemical processes] or to [heat in an isolation chamber]..$^{28}$

Put in fire, wood is consumed; submitted to the alchemical operations (samskāra) of calcination or oxidation, mercury is transmuted; heated in an isolation chamber (putapāka, PVV 54,23, PVA 106,25), gold is refined. At the end of the process, wood will have turned into ashes; mercury will have acquired the power to dye silver (rüpyarañjanasāmarthya, PVV 54,24); gold will have reached a refined state (varnikā, kalyānasuvarnatā, PVV 54,24 and Vibh. 54, note 8). In the course of the process, fire transforms wood into coal (aingāra, PVV 55,2), then into ashes (bhasman, Vibh. 55, note 1); when coal is no longer exposed to fire, it does not return to wood: contrary to jumping, the process never needs be started anew. The states previously obtained no longer need a further intervention of fire, alchemical operations or isolated heat in order to exist: they are obtained irreversibly. Contrary to athletic effort, these agents of change can therefore engage their full power in "supplementing," rather than simply recreating, the last state that they generated, and they can do so all the way to the end of the process. ${ }^{29}$ Following this model, the existence of the improved mental quality generated by constant practice no longer depends on a further action of its cause, and therein lies its sponta-

${ }^{26}$ PVP D52b4-5/P59b4-5: dus gcig gi tshe 'ga' zhig brtse ba la sogs pa'i khyad par gyi sbyor ba thob nas yang sbyor ba la ltos pa dang bcas pas 'jug pa ma yin gyi / 'on kyang khyad par thob pa gang yin pa de ni 'bad rtsol med par 'jug pa yin no // (des na ...)

${ }^{27}$ PV 2.124: kāṣthapāradahemāder agnyāder iva cetasi / abhyāsajāh pravartante svarasena krpādayah //. Note also PVV 55,2-3: tathābhyāsajāh krpādayah punaryatnānapekșitvāt sthirāśrayatvāc ca svarasena pravartante /. muditā and upekṣā according to PVP D52b5/P59b5.

${ }^{28}$ On cāraṇa and jāraṇa (PVA 106,25, PVV 54,23; spyod pa and sbyor ba: two forms of calcination), see the (rather obscure) explanations provided at PVP D53a1/P60a1, PVT Nye D116b2/P142a8-b1 ad loc., Vibh. 54, note 5. The puta (or samputa) designates the equipment (yantra) as well as the process; see Renou/Filliozat 1985: II. $\$ 1692$.

${ }^{29}$ Based on the following explanations: (1) PVP D52b6-53a1/P59b7-60a1: yang dper na kha sbyar du bzhu ba la sogs pas gser rnam par dag pa'i mtshan nyid can gyi byang ba'i yon tan de ni kha sbyar gnyis pa bzhu ba la ltos pa med pa lta bu'o // de ltar na kha sbyar du bzhu ba phyi ma phyi ma ni gzhan dang gzhan gyi byed pa yin pas na / rim bzhin du sbyor bar byed do zhes bya ba ni rnam par sbyar ba'i mthar phyin pa'o //. (2) PVP D52b6/P59b6-7: dper na mes shing la byas pa'i tshos pa las byung ba'i yon tan ji tsam pa can gang yin pa de dang de yang de'i ngo bo'i phyir me la ltos pa med pa de lta bu de ni gags byed pa med na / thams cad thal bar gyur gyi bar du phyi ma phyi ma lhag par byed pa yin no //. (3) PVV 55,1-2: teșu yadā punar vahnyādayo vyāpriyante tadā samadhikam añgārādiviśeșam ādadhati /. 
neity. Proceeding spontaneously and having a stable substratum, compassion becomes a nature: ${ }^{30}$

Consequently, the [mental] quality that arises in those [who constantly practice compassion] becomes [their] nature; each further effor ${ }^{31}$ that is made after the one [that preceded it can] add [a new] improvement [to this mental quality compared to what it was previously].

According to Devendrabuddhi, the mental quality here discussed is none other than the great compassion that results from an extremely intense practice. ${ }^{32}$ But mahākaruñ $\bar{a}$ and *atyantābhyāsa can only properly be used to define the Blessed Buddhas and those Bodhisattvas who are far advanced in their career. Moreover, the fact that this mental quality has become a svabhāva/prakrti is due, according to our two commentators, to its durable substratum (sthirāśraya). ${ }^{33}$ And as we will see below (\$4.5), that property is an exclusive characteristic of the mental series of the Bodhisattvas and Buddhas, i.e., of those who decline nirvāna or, in other words, the cessation/extinction of the mental continuum. Among those Bodhisattvas, each successive state of the mental quality is as irreversibly acquired (susthita, PVV 55,8) as those of consumed wood, mercury that is being calcinated, or gold in the process of refinement. The addition, through practice, of successive improvements can therefore last all the way to the final stage where the increased quality forms the very nature of the mind. ${ }^{34}$

At PV 2.126 and 129-130, in order to make explicit the contrast with the examples advanced by Kumārila, Dharmakīti describes the type of causality that is specific to mental events like karuna and prajñ $\bar{a}$; those three verses also show how each successive state of the mental quality is retained and then increased: ${ }^{35}$

And since mental events (buddhi) such as compassion grow out of a previous seed of the same type, how could they stagnate (sthiti) when practiced constantly? (...) Arising out of its own seed, compassion will come to form the entire essence of the mind[, i.e., the mental series], provided that it is not destroyed (bādhyate) by its opposing (vipakșa $)^{36}[$ dharmas] which [also] arise out of their own seeds. Indeed, each preceding exercise con-

${ }^{30}$ PV 2.125: tasmāt sa teșām utpannah svabhāvo jāyate guṇah / taduttarottaro yatno viśeșasya vidhāyakah //. Note the following explanations of tasmāt and svabhāvo jāyate: (1) PVP D53a2/P60a2-3: gang gi phyir brtse ba la sogs pa goms pa las skyes shing 'byung ba'i yon tan yang sbyor ba la ltos pa can ma yin pa dang / rten brtan pa can yin pa de'i phyir; PVV 55,6: tasmāt svarasavāhitvāt. (2) PVP D53a2-3/P60a3-4: rang bzhin nyid du 'gyur te / 'bad rtsol la ltos pa med par rang gi ngang gis 'jug pa; PVV 55,6-7: svabhāvo jāyate manasah prakrtir bhavati /.

31 On this apparently untimely reference to effort (yatna), see note 115 below.

${ }^{32}$ PVP D53a4-5/P60a6: skyes bu rnams kyi snying rje chen po shin tu goms pa yod pa can; note also PVV 55,6: teșām abhyāsavatām puṃsām.

33 PVV 55,3: sthirāśrayatvāe ca; for PVP D53a2/P60a3, see note 30 above.

34 “To the final stage" according to PVP D53a3/P60a4-5: khyad par phyi ma phyi ma mthar phyin pa'i bar du byed pa yin no, and PVP D53a4/P60a5-6: goms pa las shin tu mthar thug par 'gro ba yin te.

${ }^{35}$ PV 2.126, 129-130: yasmāc ca tulyajātīyapūrvabījapravṛddhayaḥ / krpādibuddhayas tāsām saty abhyāse kutah sthitị // krpā svabījaprabhavā svabījaprabhavair na cet / vipakṣair bādhyate citte prayāty atyantasātmatām // tathā hi mūlam abhyāsah pūrvah pūrvah parasya tu / kṛpāvairāgyabodhādeś cittadharmasya pātave //.

${ }^{36}$ Note PVV 56,4: vipakṣair dveșādibhir bādhyate svotpattyā vyāhanyate ... 
stitutes the cause $(m \bar{u} l a)$ [, not of the production, but $\left.{ }^{37}\right]$ of the [improved] acuity (pātava) of [each] new mental event of compassion, detachment or understanding.

As long as the causal complex (hetusāmagrī, PVP D53a7/P60b2) remains unchanged and as long as compassion's opposing dharmas, like hatred, are not cultivated, compassion generates compassion. It is the immediately antecedent condition (samanantarapratyaya) of its ulterior phases, and their "material cause" (upādānakārana). ${ }^{38}$ And in so far as the psychological process falls within a dynamic of mental cultivation or constant practice, each mental instance of compassion, rather than being identical to the previous one, tends to be stronger. Therefore, each phase of compassion does not only exist due to the phase immediately preceding it, but also increases relative to its predecessor, until it will reach the climax of its development: its cultivation will lead compassion to form gradually the essence of the mental series, a nature henceforth free of all opposing or contradictory dharmas (viruddha ${ }^{\circ}$, virodhidharma) ${ }^{39}$ Dharmakīrti is therefore able to conclude: ${ }^{40}$

With constant practice, [a mental series can therefore] consist in compassion, as is the case for repulsion, dispassion and concupiscence[, all of which also have the power to proceed spontaneously in those who cultivate them intensely].

${ }^{37}$ According to PVP D54a3-4/P61a8-b1 and PVV 56,9.

${ }^{38}$ upādānakāraṇa at PVP D53a6/P60b1; samanantarapratyaya at PVV 55,12-13 and 56,3-4. A notable antecedent to this position is found at MSAVBh D79b2-3/P94b4-5 where it is meant to explain MSABh 131,11 (samanantarapratyaya, ad MSABh $17.63 \mathrm{~d}_{2}$ [svabhāvatvāt]]): snying rje dang ldan pa'i sems dang sems las byung ba snga ma 'gags / de dang rang bzhin gcig la snying rje dang ldan pa'i sems dang sems las byung ba phyi ma 'byung ste / snga ma 'gags pa ni de ma thag pa'i rkyen to //. "The preceding [group of] cittacaitta endowed with compassion [having] come to an end, a new [group of] cittacaitta is produced that has the same nature (ekasvabhāva) as the [previous one]; the previous [group, i.e. the one that] has come to an end, is the immediately antecedent condition." MSAT D139a6-7/P156b6-7, edited in Maithrimurthi 1999: 403: sems dang sems las byung ba'i tshogs sngar byung ba ni snying rje skye bar 'gyur ba'i mtshungs pa de ma thag pa'i rkyen to //. "Das vorher entstandene Bündel von Geist und geistartigen Faktoren ist die unmittelbar vorangehende gleichartige Bedingung, aus der das Mitleid entsteht." Translation by Maithrimurthi 1999: 425. In the context of the MSA 17.63/MSABh/MSAVBh/MSAT corpus ad loc., the threefold suffering (duhkhatätraya) forms the ălambanapratyaya (condition as object) of compassion; the $v \bar{a} s a n \bar{a}$ (in the ălaya, MSAVBh) is its hetupratyaya (condition as cause); the (kalyāna)mitra is its adhipatipratyaya (dominant condition).

39 Based on PVV 56,5: prayāty atyantasātmatām vipakșāsañkīrṇasātmatām prakrtitām /. See also notes 11-12 above, and PVP D53b7/P61a4-5, PVV 55,28. On the vi\%pratipakșa, see Maithrimurthi 1999: 191; see also Traité III.1242 and note 2 for references. Note also MSABh 1,11-12 ad MSA 1.1 (tanmayah): tanmaya iti kārunyamayah, and MSAVBh Mi D8a7-b1/P8b7: byang chub sems dpa' rnams ni snying rje dang ldan pa'i rang bzhin can yin no zhes bya ba'i don to; MSAVBh Mi D6a2-3/P6b1: byang chub sems dpa' rnams snying rje'i bdag nyid du gyur pas...

${ }^{40}$ PV 2.131ab: krpātmakatvam abhyāsād ghṛnāvairāgyarāgavat/. The definition of ghrnāa at PVP D54b1/P61b7 is: mi gtsang ba la smod pa'i mtshan nyid can mi gtsang ba, which is close to Vibh. 57, note 1: aśucivi[ju]gup $[s] \bar{a}$, so that it can be reconstructed as: *aśucivijugupsālakṣan̄a ghrnāa. "Repulsion is defined as disgust of the impure." The definition of vairāgya at PVP D54a7/P61b5-6 is: grol ba rnams kyi bde ba dang sdug bsngal dag la skyo ba dang skyo ba med pa'i mtshan nyid can gyi chags pa dang bral ba, which is close to Vibh. 57, note 1: sukhaduhkhayor udvegānudvegau, so that it can be reconstructed as: *muktānām sukhaduhkhayor udvegānudvegalakșanam vairāgyam. "The dispassion of those who are delivered is defined as retreating from pleasure and not retreating from suffering." See also PVT Nye D116b7-117a1/P142b8-143a1 (where *sukha udvegah $=$ *asaktilasanga, and duhkhe 'nudvegah $=$ *apratigha). 
2.6. We now have enough theoretical elements on hand to understand why the example of jumping is irrelevant to the case under scrutiny. Dharmakirti spells this out at PV 2.127-128, of which the first verse reads as follows: ${ }^{41}$

Contrary [to compassion, which proceeds from compassion itself], the [next] jump does not [proceed] from the [previous] jump, [but from physical strength and applied effort; $;{ }^{42}$ and] since the two causes of [jumping, physical] strength and [applied] effort, have a fixed capacity, ${ }^{43}$ the [resulting] jump [also] has a fixed nature, [and its potential increase is therefore finite].

But someone may object: ${ }^{44}$ "if the jump proceeds only from [physical] strength and effort, [and] not from its homogeneous [antecedents], it should already be of such a measure (tâvatparimāna) before [our] practice." PV 2.128 answers that objection: ${ }^{45}$

[If] this [man] does not initially jump as [he jumps] later after [practicing, it is] because [the weight generated by phlegm, etc., has made his] body deficient; [but] once [that] deficiency is progressively eliminated through effort, [the body's] own strength [becomes] stable. ${ }^{46}$

Let us consider the example of a person determined to improve his ability to jump. Because the abundance of phlegm (ślesman) in his body makes him too heavy (gaurava) ${ }^{47}$ he cannot jump more than one cubit (hastamātra). But with athletic effort - gymnastics, etc. (vyāyāmādi) - applied over time, he will eliminate little by little his excessive weight, ${ }^{48}$ and his body will recover its own strength. As spectacular as progress may be while the person's physical condition and training continue to advance, his progress will nonetheless tend to stagnate as he comes closer to his maximum athletic potential. For indeed, since jumping is conditioned by causes that have a limited potential, it is itself liable to a limited progress. More importantly, since none of the acquired improvements create a solidly established (susthita) basis for ulterior efforts, everything must always be started anew. ${ }^{49}$

${ }^{41}$ PV 2.127: na caivam lan்ghanād eva làighanam balayatnayoḥ / taddhetvoh sthitaśaktitvāl lañghanasya sthitātmatā //.

42 According to PVV 55,17-18: yathā krpādibhya eva kṛpādayah / tathā na lañghanād eva lañghanam api tu balayatnābhyām /. Compare with PVP D53b2-3/P60b6-7.

${ }^{43}$ sthitaśaktitva is glossed as sāmarthyaniyama at PVV 55,18 and PVP D53b4/P60b8.

${ }^{44}$ According to PVV 55,20-21: yadi balayatnābhyām eva lañghanam na svabhāvajātīyāt (?) tadābhyāsāt prāg api tāvatparimānam syād ity āha ... PVP D53b4-5/P61a1-2: gal te stobs dang 'bad rtsol dag las mchongs pa yin gyi / rang gi rigs las 'jug pa can ni ma yin te / 'di ltar goms pa'i dus phyis skyes bu'i sa ji tsam chod pa can gyi mchongs pa yin pa de ltar sngar yang ci'i phyir mi 'gyur zhe na /.

45 PV 2.128: tasyādau dehavaigunyāt paścādvad avilañghanam / śanair yatnena vaigunye niraste svabale sthitih //.

${ }^{46}$ PVP D53b6-7/P61a3-4: ji srid bgrod par bya ba nyid yin par phyin pa yin gyi / lhag par ma yin pa de ltar na / 'di las ring du song ba ma yin pa zhes bya ba la kha na ma tho ba yod pa ma yin no //. "He will go only as far as it is possible [for him] to go and no further; hence he cannot go beyond that point; [our position] is therefore flawless." See also PVV 55,26.

${ }^{47}$ According to PVP D53b6/P61a2-3: bad kan la sogs pas lus mi mthun phyir te / lci ba nyid kyi rgyu'i phyir ro //. PVV 55,24: dehavaigunyā̄c chleșmādikrtagauravāt/. See also note 13 above.

48 According to PVP D53b6/P61a3: phyis kyang rtsol bas rim gyis mi mthun pa bsal na lus lci ba med pa na ... PVV 55,25: śanair yatnena vyāyāmādinā vaigunye niraste ...

49 Śāntarakșita and Kamalaśīla do not hesitate to hold that the sthitotkarșatā of the jump itself is not established 
2.7. A second condition remains to be met for Dharmakīrti's argument to hold: the substratum of this improvement must be durable enough to carry this deployment to its end. If Dharmakirti has remained silent on this issue, his successors did not hesitate to show that only Bodhisattvas aspiring to become Buddhas met this condition, contrary to the Hearers and Buddhas-for-themselves. PV 2.198 summarizes the issue: $:^{50}$

And since the compassion [of śrāvakas is] weak, [they make] no great effort to remain [in samsāra]. But [the great saints who are] devoted to others [and] whose compassion is great do remain [in sampsāra].

The intensity of the compassion characteristic of those various "anthropo-religious" types conditions the duration of their respective stay in samsāra. Motivated, as we will see (\$5.4), by the fear of samsāra and by the correlated desire for a prompt liberation, the śravvaka - but also the arhat and the pratyekabuddha - reach nirvāna too quickly to be able to develop compassion to its utmost level. The Bodhisattva, on the other hand, is motivated only by his desire to rescue other beings: his own good corresponds to the good of others. To be able to teach the path (or the four noble truths) to sentient beings, he will cultivate compassion to its utmost limit and will consequently extend his samsāric existence. The diversity of motivations therefore determines the duration of the mental series that serves as a substratum for the development of compassion. ${ }^{51} \mathrm{We}$ owe it to Devendrabuddhi to have correlated this theme with the issue of the durability of the substratum: ${ }^{.2}$

If the substratum is durable, [each new effort] will bring the next improvement. If it is not, [then] what nature would the noble Hearers (āryaśrāvaka) ever acquire [through compassion], they whose mental series are interrupted [upon attaining nirvāna]? Those who seek the good of the world (jagaddhitaișin), however, do not have substrata that are rendered unstable by the interruption of their [mental] series [due to entry into nirvāna].

(asiddha), a position of which there is no trace in Dharmakīti and his direct commentators. To do so, they use the notion of manojava ("fast like the mind"), which is the third type of rddhi applicable to motion (see AK 7.48ab and Kośa 7.113, note 2). TSP K893,15-18 ad TS no. 3425-3427/S1080,18-22 ad TS no. 3424-3426: samādhibalaviśesaprayogāl lañghanasyāsmābhir ișyata evātyantaprakarșavartitvam, yathā bhagavato manojavā nāma siddhih (TSP ${ }_{\text {tib }}$ Ye P377b8: rdzu 'phrul) pathyate ... na cāsyā bādhakạn pramānam asti / nāpy adarśanamātrena pratiksepo yukto 'tiprasangāt /. "We [Buddhists] accept [the claim] that jumping, because it is connected to the particular power of a [mental] concentration, can reach a very high [level of] development: the scriptures tell (pathyate) [us] for example that the Blessed [Buddha] possesses a miraculous power named manojava $\bar{a} . .$. Now, no pramāna can invalidate [the existence] of [that miraculous power], and neither can it be rejected simply because it is not perceived, for this would be absurd."

${ }^{50}$ PV 2.198: mandatvāt karunāyāś ca na yatnah sthāpane mahān/ tișthanty eva parādhīnā yeșām tu mahatī $k r p \bar{a} / /$.

${ }^{51}$ This can be compared to the general motif of apratișthitasamsāranirvānatva (MSABh 124,23) as it is developed at MSA(Bh) 17.32-33: see Maithrimurthi 1999: 369-370 and, for the useful MSATT D136a3-5/ P153a58 ad MSABh 17.32, Maithrimurthi 1999: 413-414; see also Nagao 2000: 2-4 and Viévard 2002: 270-271. See as well Sthiramati's excellent overview at MSAVBh D63b5-64a4/P75b2-76a3 ad MSA(Bh) 32, and MSAVBh D64a4/P76a2-3: snying rje yod pas mya ngan las 'das pa la gnas pa ma yin / shes rab yod pas 'khor ba la gnas pa ma yin no //. "Because of [his] compassion, [the Bodhisattva, contrary to the Hearers and Buddhas-for-themselves,] does not stay in nirvāna. [But] because of [his] insight, [i.e., because of his penetration of the two selflessnesses, the Bodhisattva] does not stay in samsāra [either, contrary to the Profanes]." See also $\S 4.4$ below.

${ }^{52}$ PVP D52b3-4/P59b2-4: rten brtan pa nyid du gyur pa na khyad par phyi ma byed par 'gyur ro // de lta ma yin na 'phags pa nyan thos rgyud rgyun chad pa can rnams de'i bdag nyid du gyur pa gang yin / 'jig rten la phan par bzhed pa rnams ni rgyud rgyun bcad pas kyang rten mi brtan pa nyid ma yin no //. 
The close integration of this theme with Mahāyāna buddhology culminates in the works of Śāntarakṣita and Kamalaśîla. ${ }^{53}$

\section{Compassion and the initial impulse toward the practice of compassion}

3.1. According to Iwata, Dharmakīrti holds that compassion arises (or rather, becomes actualized, in the sense of the prabodha of an impregnation, vassana) from the direct realization that everything that is conditioned (samskāra), in particular the aggregates of appropriation, is suffering in so far as it is conditioned and thus impermanent. ${ }^{54}$ Iwata's analysis rests on two important comments made by Dharmakīrti at PVSV 9,13 (duhkhaviśesadarśanamātrena) and PV 2.196cd (duhkhasantānasamsparśamātrena). On that hypothesis, compassion would result from the direct cognitive confrontation ${ }^{55}$ with (a particular type of) suffering. Iwata's hypothesis is not without problem, however, since the direct realization of the painfulness of what is conditioned, in so far as it belongs to the arryas who understand the emptiness of the personality (pudgalaśunyatā), does not account for the arising of compassion among the Profane and Heretics, i.e., it does not account for the initial impulse toward $a b h y \bar{a} s a$. For them, indeed, compassion rests entirely on the (erroneous) superimposition of a personal being: their compassion is sattvālambanā karuña which, among the three kinds of karuñā, is the only one classified as passion (see below, §4).

(1) In this regard, Śākyabuddhi and Karṇakagomin will confirm my hypothesis in that they do not hesitate to gloss duhkhaviśeșa (PVSV 9,13) as samskāraduḥkhatā, ${ }^{56}$ a type of suffering the intuition of which is traditionally reserved for aryas. ${ }^{57}$

(2) The context of the second comment in fact also plays in favour of an interpretation of duhkhasantanasamsparśa as a compassion characteristic of the aryas: "If "If we know [the truth of] suffering [in its four aspects of impermanence, painfulness, emptiness and insubstantiality], the production of compassion that proceeds from prior conditioning is a property of the [suffering] entity [itself] and [arises] without considering any living being. Passion ( $r \bar{a} g a$ ) [arises however] from the superimposition of a distinct (antara) self [that is permanent, happy and substantial in nature] on something that does not have such nature[, since it consists merely in the aggregates]. Compassion, [on the other hand,] is born through nothing but [cognitive] contact with the suffering series (duhkhasantāna) [, and not through the erroneous superimposition

\footnotetext{
53 TSP K894,23-27 ad TS no. 3433/S1082,13-17 ad TS no. 3432, to compare with TSP ${ }_{\text {tib }}$ Ye P378b4-7.

54 See Iwata 2011, pp. 216-217.

${ }^{55}$ For example, PVP D84a6/P96b7: goms pa las sdug bsngal tsam mngon du byed pa'i sgo nas 'jug pa; PVV 78,10-11: sammukhībhāvamätrena.

${ }^{56}$ PVṬ Je D24b4-5/P29b1 = PVSVṬ 52,28-53,7: duhkhaviśeṣadarśanamātreṇeti samskāraduḥhatānirūpaṇamātrena.

57 AKBh 329,11-12 ad AK 6.3: sarve tu saṃskārāh samskāraduḥkhatayā duḥkhāh / tāms tv āryā eva paśyanti //. See Kośa 7.125-126.

${ }^{58}$ PV 2.195-196 (with 'viruddhasya left untranslated!): duhkhajñāne 'viruddhasya pūrvasamskāravāhin̄̄ / vastudharmo dayotpattir na sā sattvānurodhin̄̄ // ātmāntarasamāropād rāgo dharme 'tadātmake / duhkhasantānasamsparśamātrenaiva dayodayah//. See PVP D84a4b2/P96b5-97a4, PVT Nye D131a5-7/P161b3-7, PVV 78,4-18.
} 
of a self: that is the reason why compassion is not a passion]." Vibhūticandra, incidentally, is right in seeing in this passage a reference to the dharmālamban $\bar{\imath} k r p \bar{a}$ characteristic of the $\bar{a}$ rya(/śrāvaka/pratyekabuddha), as we will see below. ${ }^{59}$

(3) Some further arguments will also support my hypothesis. First, the direct realization of the suffering nature of what is conditioned does not appear among the causes and conditions mentioned by Devendrabuddhi (and Śākyabuddhi) to explain why anyone would begin the practice of compassion (see below, §3.2). Also, the context of Dharmakīti's comments suggests that the compassion here intended is already abhyāsaja ${ }^{60}{ }^{60}$ so that the darśana/samsparśa to which Dharmakīrti refers could not serve as the cause of the initial practice of compassion. Finally, both of Dharmakirti's comments appear in the context of an argument advanced to deny that compassion is necessarily a passion, i.e., that compassion necessarily entails the cause of suffering and the passions (sattvadarśana/satkāyadrști); ${ }^{61}$ they could not, therefore, apply to the only type of compassion considered to be impure, i.e., to sattvālambana karunāa. I am therefore inclined to believe that the direct cognitive confrontation with suffering is characteristic of the compassion of the arryas/śrāvakas/pratyekabuddhas (and, of course, of the compassion of the advanced Bodhisattvas and the Tathāgathas) who have come to understand the suffering nature of what is conditioned, i.e., we are here in the presence of dharmālambana karuna $\bar{a}$, which follows from dharmaśunyatā. In other words, those two comments made by Dharmakīrti do not pinpoint the cause of the initial impulse toward abhyāsa, but rather, they point to that which, due to the universal nature of suffering, makes compassion coexist with any of the thoughts of those saints who are advanced on the path(s).

3.2. Devendrabuddhi, however, identifies five (alternative) factors to account for the initial impulse toward the practice of compassion. Sākyabuddhi appears to divide those five factors into two causes (hetu) and three conditions (pratyaya).$^{62}$ Based on this analysis, the causes of the impulse toward practice are: (1) attachment to qualities/advantages (yon tan la chags pa las $s a m)^{63}$ and (2) [the quality of being] a living being of a particular type (sems can gyi khyad par

59 Vibh. 78, note 3 ad PV 2.195: etena dharmālamban̄ krpoktā /.

${ }^{60}$ See PV 2.195, quoted in note 58 above, with the following explanations for pūrvasamskāravāhinī: PVP D84a5/P96b6-7: 'du byed snga ma 'jug pa can / de dag gis sngar yang snying rje goms par byas shing de goms pas las phyis kyang brtse ba skye ba yin no //. PVV 78,8: pūrvasaṃskāravāhinī pūrvābhyāsapravrttā. Note also PVSV 9,12-14: asaty apy ātmagrahe duhkhaviśsesadarśanamātreṇābhyāsabalotpādin̄̄ bhavaty eva karuñā/. "[Contrary to passion,] compassion, which is produced by the power of constant practice, occurs due to the perception of a particular suffering[, namely, the suffering of what is conditioned], even when there is no grasping at a self."

${ }^{61}$ See Manorathanandin's concluding remark ad PV 2.195 (PVV 78,10-11): unmūlitātmadṛștīnām api ... sammukhībhāvamātreṇa dayotpadyata ity arthah /. Devendrabuddhi's commentary ad PV 2.196cd (PVP D84b12/P97a2-4) reads: sdug bsngal rgyun gyi 'dus reg tsam spyod yul thob par gyur pa tsam nyid las brtse ba skye ba yin / brtse ba 'byung ba yin gyi / rang bzhin gzhan sgro btags pa las ma yin pa de ltar na 'dod chags kyi mtshan nyid las bzlog pa'i rang bzhin can yin pa'i phyir 'dod chags snying rje ma yin no //. Note also PVT Nye D131a7/P161b6-7 ad loc.: 'dus reg tsam zhes bya ba la tsam smos pa ni don lhag par sgro 'dogs pa spangs pa'i phyir ro //.

${ }^{62}$ PVT Nye D88b5/P108a4: ... 'dis ni rgyu'i stobs bshad do // rkyen gyi stobs ni gzhan zhes bya ba la sogs pa smos te $/$.

${ }^{63}$ Śākyabuddhi's explanation does not add anything substantial for our understanding of the first factor (PVT 
las sam). The conditions of the said impulse are: (3) the action of other [beings] acting for the good of others (gzhan gyi don la 'jug pa gzhan dag gi byed pa las sam), (4) the service [provided] to them (de bsnyen pa las sam), and finally (5) the personal desire [to proceed with this practice] (bdag nyid'dod pa las sam) ${ }^{64}$

3.3. First a few words about the second causal factor advanced by Devendrabuddhi, namely, *sattvaviśeșa, or "[the quality of being] a living being of a particular type." Sākyabuddhi interprets sattvaviśeșa as "[the quality of possessing] a particular nature" (prakrti\%/svabhāvaviśeșa), and goes on to explain it briefly by referring to the notion of gotra (tib. rigs), or family. ${ }^{65}$ The author of the MSA XVII.34 also holds that the compassion of Bodhisattvas can be due to their very nature (prakṛti), which the bhāṣakāra explains as gotraviśeșatah, "due to a particu-

Nye D88b4/P108a2-3: yon tan dag la 'ga' zhig chags pas goms par byed pa'i phyir de* goms pa la 'bad rtsol dang ldan par 'gyur ro // snying rje yang khyad** par 'phags pa'i yon tan yin par dam pa rnams bzhed pa de bas na yon tan la chags pa las snying rje la 'jug par 'gyur ro // *D te; **P khyab. That explanation borrows from Dharmakīrti's religious anthropology as it appears at PV 1.221 [with PVSV 111,1-11] = PV 2.210; see also PVP D90a1-3/P103b7-104a2 [with PVT Nye D134b3-5/P166a1-3] and TSP K874,5-17 ad TS no. 3338/S1058,12-1059,1 ad TS no. 3337). However, Vasubandhu's (?) and Sthiramati's commentaries to MSA 17.34 are more directly useful to our exegesis. Maitreya(nātha) declares: "Dieses Mitgefühl $(k r p \bar{a})$ [der Bodhisattvas], die Mitleid zum Wesen haben, ist ... vierfach: ... [b.] Mitgefühl aufgrund von Überlegung (/Abwägen) ...” (MSA 17.34, partially: krpā ... pratisaṃkhyayā ... karunātmakānām //. Translated by Maithrimurthi 1999: 370). That pratisamkhyā is interpreted as gunadoṣaparīkșana at MSABh 125,11: "die gründliche Untersuchung der Vorzüge [des Mitgefühls] und der Fehler(/Mängel) [des entsprechenden Faktors]" (Maithrimurthi 1999: 370). For Sthiramati's explanation of doșaparikșaṇa, see MSAVBh D64b6-65a1/P76b7-77a2, edited and translated in Maithrimurthi 1999: 441, note 34. As for the examination of the qualities/advantages, Sthiramati provides the following explanation: "The examination of the qualities/advantages [to practice compassion consists in] considering the qualities/advantages in the following manner: 'Showing friendliness and compassion to sentient beings is appropriate for the Bodhisattva [who wishes to behave] in conformity with compassion.' Alternatively, [it consists in] considering these qualities/advantages by reflecting in a manner that has been presented earlier: 'All these faults/disadvantages do not appear among those who are well established in [immeasurables] like friendliness.' For the good of other sentient beings, he[, i.e., the Bodhisattva,] does not leave samsāra, [but still remains] pure." (MSAVBh D65a1-2/P77a2-3: yon tan kun tu rtog pa ni sems can la byams pa dang snying rje byed pa ni snying rje dang rjes su mthun pa'i byang chub sems dpa' cha yin no zhes yon tan du rtog pa'o // yang na gong du bshad pa ltar nyes pa de dag thams cad ni // byams pa la sogs pa gnas mi 'byung // nyon mongs med par sems can don // 'khor ba 'dor bar mi byed do // zhes bya ba la sogs pa' $i$ tshul du rtog pa ni yon tan rtog pa'o //. The verse here quoted is MSA 17.27, edited by Maithrimurthi [1999: 336] as follows: ete sarve dosā maitryādisu susthitasya na bhavanti / aklistah samsāram sattvārtham no ca saṃtyajati //. MSABh 123,24-25 ad loc.: iti brāhmavihārayoge dvividham gunam darśayati / yathoktadoșābhāvam akliștasya sattvahetoh samsārāparityāgam /. "Mit diesem Vers [iti] zeigt er [d.h. der Verfasser], daß sich bei Übung der brahmischen Zustände zweierlei Vorzüge [einstellen: nämlich] daß die obengenannten Fehler nicht vorhanden sind, und daß man um der Lebewesen willen den Samsāa nicht aufgibt, ohne aber [durch ihn] befleckt zu werden." Translated in Maithrimurthi 1999: 366.)

${ }^{64}$ PVP D16a5/P18a3-4. On the fifth factor, see PVT Nye D88b6-7/P108a5-6: bdag 'dod pa las zhes bya ba ni de dag gis byed pa'am bsnyen pa las ma yin mod kyi / 'on kyang bdag nyid de snying rje 'dod pa yin no //.

65 PVT Nye D88b5/P108a3-4. Let us remember the "classical” definition of gotra as șadāyatanaviśeșa, "a specificity of the six sensory extension bases," which is caracteristic of the gotra existing by nature (prakrtistha, as opposed to acquired gotra, samudānīta). See BoBh D2,4-9/W3,1-9 (and particularly D2,5/W3,2-3: tatra prakrtistham gotram yad bodhisattvānām șadāyatanaviśeṣah /), Seyfort Ruegg 1969: 88 and MSAVBh Mi D2a2-5/P2b1-4. 
lar/specific gotra." ${ }^{66}$ The fact that Śākyabuddhi analyses this *sattvaviśeșa = gotra as a cause for the practice of compassion should not come as a surprise, however, for both the MSA(Bh) and the BoBh identify the bodhisattvagotra as the cause of conventional bodhicitta (sänketika ${ }^{\circ}$ ) and the career that culminates in awakening. ${ }^{67}$ Moreover, the bodhisattvagotra is intrinsically linked to compassion since, indeed, among the four marks (linga) of the bodhisattvagotra listed at MSA(Bh) 3.5, it is compassion (kārunya and ādiprayogata eva kārunyam sattveșu, MSABh 11,18) that figures in first place. ${ }^{68}$

3.4. Now let us consider the first two conditioning factors mentioned by Devendrabuddhi. The initial impulse toward compassion can be conditioned "by the action of other [beings] acting for the good of others (*parārthavrtti) or by the service (sevā) [provided] to those [compassionate beings]." By "action" (byed $p a=* k r i y \bar{a}$ ?), we must understand the invitation to engage in compassion $^{69}$ (snying rje nges pa sbyar ba $=*$ karunāsamviniyojana?), an invitation which comes from "Bodhisattvas who have practiced compassion [constantly]."70 As for "the service [provided] to those [compassionate beings]," it is interpreted as follows: "Even if they did not invite [him] to engage [in compassion], he keeps company with [those beings] who act for the good of others, he serves them, and because of that he acquires qualities [such as compassion]." The allusion to service is clear: Devendrabuddhi and Śākyabuddhi refer to the wellknown theme of the kalyānamitra, or "spiritual friend," which is regularly connected with the complex formed of the two other themes of gotra and conventional bodhicitta. ${ }^{72}$ The fact that keeping company with a spiritual friend conditions compassion can easily be documented. While it is claimed at MSA VII.63cd that ${ }^{73}$ "the compassion of Bodhisattvas [notably proceeds due to] ... a friend," Sthiramati comments, based on the MSABh: ${ }^{74}$ "Once [we can] rely upon a

${ }^{66}$ MSABh 125,11 ad MSA 17.34. Note Sthiramati's explanation at MSAVBh D64b5-6/P76b6: rang bzhin dang ni zhes bya ba la / rang bzhin ni rigs la bya ste / snying rje'i rigs yod pa las snying rje 'byung ba ni rang bzhin zhes bya ste /. “... als 'Natur' wird die Anlage (gotra) bezeichnet; [d.h.] als 'Natur' wird die Tatsache bezeichnet, daß Mitleid auftritt, weil die Anlage für Mitleid vorhanden ist.” Edited and translated in Maithrimurthi 1999: 414, note 33 .

${ }^{67}$ See in general Seyfort Ruegg 1969: 77-94, together with BoBh D10,12-13/W15,11-12 and MSABh 15,2.

${ }^{68}$ See also Maithrimurthi 1999: 268 and notes 153-154.

${ }^{69}$ PVṬ Nye D88b6/P108a4-5: byed pa ste / snying rje nges par sbyar ba'o //.

${ }^{70}$ PVT Nye D88b5/P108a4: snying rje goms pa can gyi byang chub sems dpa' dag gis ...

${ }^{71}$ PVT Nye D88b6/P108a5: de dag gis nges par ma sbyar ba de lta na yang gzhan gyi don la 'jug pa rnams dang lhan cig gnas shing de bsnyen pa las de yon tan can du 'gyur ro //.

${ }^{72}$ This could possibly explain Ravigupta's allusion to kalyāṇamitra at PVṬ. ${ }_{\mathrm{R}}$ D316b2-3/P164b4-5 ad PV 2.34ab (reference found in Iwata 2011: 219, note 28). Cf. perhaps also PVA 107,5 (= v. 585): smaranaśravaṇenāpi kṛāīinām pravartanam / na ca pratyupakārādisavyapekșāh kṛpādayah //.

${ }^{73}$ MSA 17.63cd: karuṇā bodhisattvānām ... mitrāt ...

${ }^{74}$ MSAVBh D80a2/P94b3-4: dge ba'i bshes gnyen la brten nas / dam pa'i chos nyan pa'i dbang gis snying rje skye ste / de ni bdag po'i rkyen to //. Compare with MSAVBh D142b5-6 ad MSA(Bh) 9.76a (dhāranāt), where Sthiramati associates finding a spiritual friend with the Profane. Note also MSABh 131,10-11: uttarārdhena (= MSA $17.63 \mathrm{~cd})$ yathākramam hetumitrasvabhāvaih karunāyā hetvadhipatisamanantarapratyayān saṃdarśayati. For a translation, see Maithrimurthi 1999: 387-388. MSAT D139a6/P156b6, edited by Maithrimurthi (1999: 403): dge ba'i bshes gnyen gyi dbang gis snying rje kun tu spyod pa gang yin pa de ni bdag po'i rkyen 
spiritual friend, compassion arises through listening to the excellent Dharma (saddharma): such is the dominant condition (adhipatipratyaya)." Whereas Sthiramati refers to the importance of hearing the excellent Dharma, the BoBh says that it is up to the kalyanamitra to teach the path to awakening. This is because the spiritual friend is the teacher, the religious instructor, whereas the "novice" Bodhisattva who serves as his attendant becomes his disciple. ${ }^{75}$ The master, who also acts as a friend, therefore enjoys the liberty to exhort his pupil to practice compassion, to follow his own engagement as an example, he who is described by our sources as a compassionate being acting for the good of others. ${ }^{76}$ Let it be noted, finally, that as in the case of gotra, the theme of kalyānamitra is closely connected with that of cittotpāda, a conventional thought of awakening for which the spiritual friend is regularly held as being one of the causes. ${ }^{77}$

3.5. We therefore find Devendrabuddhi and Śākyabuddhi, and after them Kamalaśīla ${ }^{78}$ and Ravigupta, using a motif that had already been given a prominent position in major Mahāyāna sūtras and śâstras (essentially of Idealist persuasion): they present the gotra as a cause for the compassion motivating the Bodhisattva, whereas keeping company with a kalyanamitra is presented as a condition for the Bodhisattva's inclination toward the same compassion, so that gotra and kalyanamitra together contribute to the production of the thought of awakening. Dharmakīrti, it is true, does not say a word about those three central themes. But if, as I will attempt to demonstrate below (\$5), Dharmakīrti indeed considered compassion to be the direct cause of the thought of awakening, we will be less hesitant to conjecture that together with his nearly unanimous tradition, he also tacitly recognized gotra and kalyānamitra among the causes/conditions of bodhicitta.

to //. "Das Auftreten des Mitleids aufgrund des Einflusses eines guten (d.h. spirituell günstigen) Freundes (kalyānamitra) ist die Bedingung, [die im] beherrschenden Faktor [besteht]." See note 38 above.

${ }^{75}$ BoBh D163,23/W238,1: bahuśruto bhavati nāvyutpannabuddhih; D164,23/W239,16: anuśāsako bhavati/ dharmadeśako bhavati /. Note also, via negativa, BoBh D7,15-16/W11,4-6: ... bodhisattva ādita eva kalyānamitram na labhate 'viparītabodhimārgadaiśikam buddham vā bodhisattvam vā/. vineya at BoBh D163,16/ W237,17 and D164,21/W239,14; BoBh D163,18-19/W237,21-22: ... kalyānamitrasyāntikād bodhisattvena dharmam śrnvatā ...; see also BoBh D165,6-26/W240,7-241,14. On kalyānamitrasevā, see in general BoBh D163,13-165,26/W237,13-241,14 and MSA(Bh) 17.9-16. kalyānamitrasevā is used at D164,26/W239,20-21; kalyānamitrasaṃsevā at D163,17/W237,18-19; kalyānamitraniṣevanatayā at DBhS (I BB) 13,21.

${ }^{76}$ BoBh D163,24-25/W238,3-4: anukampakaś ca bhavati kārunikah so 'dhyapeksya ...; BoBh D164,56/W238,15-16: sa hi pareșām ādita eva hitasukhaiși bhavati; BoBh D164,8-9/W238,21: samakārunyaś ca bhavati; MSA 17.10: mitrạ̣ śrayet ... krpātmakam ...

77 BoBh D10,13/W15,12,13: buddhabodhisattvakalyānamitraparigraho dvitīyo hetuś cittasyotpattaye; DBhS (I R) 11,11-13: ... suparigṛhītakalyānamitrānām ... krpākarunāahimukhānām bodhisattvānām bodhāya cittam utpadyate; MSA 4.7: mitrabalāt ... cittotpādạh ... (and MSAB̉ 15,1-2 and 5: yo hi parākhyänāc cittotpādah paravijñāpanāt sa ucyate samādānasānketikaḥ / sa punar mitrabalād vā bhavati kalyānamitrānurodhāt / ... sa punar mitrabalād adrụhodayo veditavyah /). See also Seyfort Ruegg 1969: 84-85 and 100.

78 TSP K872,3-7 ad TS no. 3338/S1055,16-20 ad TS no. 3337; see $§ 5.4$ below. 


\section{The "immeasurables" and the Bodhisattva's career}

4.1. In his commentary to PV 1.12, Dharmakīrti attempts to establish that compassion is not, or at least is not necessarily, a passion ( $r \overline{a g a}){ }^{79}$ To show that his argument is supported by Buddhist scriptures, he declares: ${ }^{80}$ "It is in fact admitted [by us Buddhists] that [immeasurables] like friendliness [not only] have beings as their objects, [but also] dharmas, etc." In so doing, Dharmakīrti refers to the well-known Mahāyāna valorization of the four traditional "immeasurables" (apramāṇa, also named brahmavihāra): friendliness (maitrī), compassion (karu$n \bar{a})$, joy (sympathetic, "co-rejoicing," muditā) and equanimity (upekșa). ${ }^{81}$ Each of these four apramānas, according to the Mahāyāna, is of three varieties: it is named sattvālambana when it takes beings as its object; it is named dharmālambana when it takes dharmas as its object, i.e., the psycho-physical events ultimately constituting the (pseudo-)person according to the Śāvakayāna analysis; and it is named anālambana, "without object," when it no longer bears upon anything at all. ${ }^{82}$ According to the presentation provided by Sthiramati in his commentary to MSA(Bh) XVII.17-18, this threefold valorization of the apramannas has two main sources, which in several respects represent two competing, though ultimately converging, exegetical trends concerning that motif: on the one hand, we have the Yogācārabhūmi (and particularly the BoBh), ${ }^{83}$ whereas on the other we have the Āryāksayamati(nirdeśa)sūtra (ANS). ${ }^{84}$ Dharmakîrti's explicit allusion to this Mahāyāna theme is very important here: first, it establishes the specific doctrinal and narrative context of the theory developped at PV 2.120-131ab; second, it offers a credible exegetical hypothesis about one of the three major features of the theory, namely, the supposed "spontaneity/mechanicity" (svarasavāhitva, etc.) of compassion.

4.2. (1) According to the BoBh, the Bodhisattva shares with the Heretics (anyatĩrthya) the immesurables of the sattvālambana type. ${ }^{85}$ Why are such apramannas said to "bear upon beings"?

79 This passage has been discussed by Dunne (1996: 535-540), whose analysis and conclusions I do not share; by Iwata 2011: 214-215, who properly shows its similarity with PV 2.195-199.

${ }^{80}$ PVSV 9,14-15: tathā hi sattvadharmādyālambanā maitryādaya ișyante /. Introduction at PVT Je D24b5/P29b2 = PVSVT 53,8: ägamenāpi samsyandayann āha ...

${ }^{81}$ Note the definitions provided by Śākyabuddhi at PVṬ Nye D116a7-b1/P142a6-7: gzhan dag gis* kha na ma tho ba med pa'i yid bde ba nyid ni dga' ba'o // rjes su chags pa dang khong khro ba'i rgyu'i yul la 'dod chags dang khong khro ba dang bral ba nyid kyi btang snyoms yin no // *D gi. On the apramāna = brahmavihāra, see Kośa 7.196-203 (AKBh 452,4-454,23), Traité III.1239-1273, Pagel 1995: 36-48, Maithrimurthi 1999.

82 See the in-depth study by Maithrimurthi, especially 1999: 215-273; Traité III.1250-1254; La Vallée Poussin 1907: 258, note 1; Pagel 1995: 41-44.

${ }^{83}$ MSAVBh D54b7/P64b4 ( $r N a l$ 'byor spyod pa'i sa). The passage has been edited, translated and discussed by Maithrimurthi (respectively in 1999: 306-307, 317-319 and 246-255); it corresponds to BoBh D166,124/W241,15-243,2 (see also Traité III.1250, note 1).

${ }^{84}$ MSAVBh D55a5/P65a3 ('Phags pa blo gros mi zad pa'i mdo). Śiks 212,2-4 = Braarvig 1993: II.352: sā trividhā āryākșayamatisūtre 'bhihitā / sattvārambaṇā maitrī prathamacittotpādikānām bodhisattvānām / dharmārambaṇā caryāpratipannānām bodhisattvānām / anārambaṇā maitry anutpattikadharmakṣāntipratilabdhānām bodhisattvānām iti /. See also the Tibetan text edited in Braarvig 1993: I.86. For a translation, see Bendall/ Rouse 1971: 204, Braarvig 1993: II.352, Pagel 1995: 138; see also Traité III.1245, 1272-1273 and V.24242425; Viévard 2002: 175, note 327.

${ }^{85}$ See BoBh D166,16-17/W242,16-17, together with MSAVBh D55a3-4/P65a1-2. Note also PVT Je 
According to Sthiramati's commentary to the ANS, ${ }^{86}$ it is because "we consider a [pseudo-]entity, the living being, as [truly] existing, and do not know the [fundamental] insubstantiality (nairātmya) of persons (pudgala) and dharmas." (2) According to the BoBh, the Bodhisattva shares the immeasurables of the dharmālambana type with the śrâvakas and pratyekabuddhas, but not with the Heretics. ${ }^{87}$ An immeasurable bearing upon dharmas is characteristic of the saint $^{88}$ "who, perceiving dharmas only, clearly understands the metonymic application of [the notion of a] living being to mere dharmas." Sthiramati's explanation goes as follows: ${ }^{89}$ "Because [an immeasurable of this type] arises after one has perceived that entities are reducible to the mere dharmas of the five aggregates such as corporality, etc., and that what is called "self" or "living being" does not exist, and that [these] five aggregates are by nature impermanent, suffering, etc." (3) As for the immeasurable of the anālambana type, it is shared by the Bodhisattvas and Tathāgatas, but not by the Heretics, śrāvakas and pratyekabuddhas. ${ }^{90}$ According to the BoBh, is "without object" an immeasurable that is cultivated by the saint without even imagining dharmas. ${ }^{91}$ Sthiramati explains. ${ }^{92}$ "No longer perceiving living beings since he has grasped the insubstantiality of persons, and without perceiving dharmas either since he has grasped the insubstantiality of dharmas, he provides an immeasurable assistance to beings."

4.3. The ANS and BBhSŚ associate the anālambanā maitrī with the Bodhisattva "who has acquired the conviction that dharmas [ultimately] have no arising" (anutpattikadharmaksāntipratilabdha). Acquiring that kșanti generally (though not uniformly) marks the entry of the Bodhisattva into the eighth level, the acala bhümih of the DBhS and niyata bhümih of the BoBh. ${ }^{33}$ It marks the irreversibility of the Bodhisattva's progression; it is the mark of the Bodhisattva who cannot regress (avaivartika). ${ }^{94}$ Whereas the sattvālambanā karuña was characteristic of the

D24b6/P29b2-3 = PVSVT 53,9: sattvālambanā prthagjanānām. On the categories of beings who direct the immesurables toward beings, see BoBh D166,3-6 and 166,9-16/W241,18-23 and 242,7-15, MSABh 121,16ff, MSAVBh D55b3-56a1/P65b3-66a2; on the stereotyped formulation of the apramānas, see Maithrimurthi 1999: 35-46, as well as Traité III.1239-1240 and 1246ff.

${ }^{86}$ MSAVBh D55a6/P65a5-6: sems can gyi dngos po yod par lta zhing gang zag dang chos la bdag med par ma rtogs pa'i phyir ro //.

${ }^{87}$ See BoBh D166,18-19/W242,17-19, together with MSAVBh D55a4/P65a2-3. Note also PVT Je D24b6/P29b3 = PVSVT 53,9: dharmālambanā āryānām /.

${ }^{88}$ BoBh D166,6-7/W241,23-242,2: yat punar dharmamātrasamjīñ dharmamātre sattvopacāram āśayatah sampaśyams tām eva maitrīn bhāvayati /.

${ }^{89}$ MSAVBh D55a1-2/P64b6-7: dngos po 'di dag gzugs la sogs pa phung po lnga'i chos tsam du zad kyi / bdag gam sems can zhes bya ba med la / phung po lnga yang mi rtag pa dang / sdug bsngal ba la sogs pa'i rang bzhin no zhes dmigs nas ... 'byung ba'i phyir ro //.

${ }^{90}$ See BoBh D166,19-20/W242,19-21, MSAVBh D55a4-5/P65a3, and MSAVBh D55a2/P64b7.

91 See BoBh D166,8-9/W242,3-5.

${ }^{92}$ MSAVBh D55a2-3/P64b8-65a1: gang zag la bdag med par khong du chud pas sems can du mi dmigs pa dang / chos la bdag med par khong du chud pas phung po lnga'i chos tsam du yang dmigs pa med par sems can la phan 'dogs pa dpag tu med par mdzad pa'i phyir ro //.

93 See DBhS (VIII C) 64,8 and 15, BoBh D253,8/W367,11, and MSABh 122,1-2 ad MSA 17.19 (Maithrimurthi 1999: 360-361).

94 Viévard 2002: 269. 
compassionate being who had not realized the insubstantiality of persons, ${ }^{95}$ and the dharmalambana karun $\bar{a}$ was characteristic of the compassionate being who had not penetrated the insubstantiality of dharmas, ${ }^{96}$ the Bodhisattva who has reached the eighth level knows that dharmas do not arise; having realized the two emptinesses, ${ }^{97}$ he no longer perceives any object that can serve to define karuna.$^{98}$ That compassion par excellence, which is concomitant with the "suppression of the subject/object polarity," ruṇā).

The attainment of dharmaksānti, however, is not the only defining feature of the revolution that occurs in the acalā bhümih. For the acalā bhümih also coincides with the suppression of all "intentional effort;" 100 it is there that the psycho-cognitive endeavor acquires its spontaneity, automaticity, mechanicity (anābhogatā): ${ }^{101}$ "Les membres de l'effort (prayogāinga) et la

95 According to Sthiramati's commentary to the ANS at MSAVBh D55a5-6/P65a4-6, the sattvālambanā karunā characterizes the prathamacittotpādika Bodhisattva, who still does not understand the twofold insubstantiality. On the prathamacittotpādika Bodhisattva, see BoBh D12,8-14,5/W18,10-20,27 and BoBh D166,2022/W242,21-24 (to be compared with BoBh D12,13-16/W18,16-21). Some useful information is also found in Braarvig 1993: II.352, note 2 (sems dang po bskyed pa'i byang chub sems dpa' ni dang po so so'i skye bo' $i$ dus na bla na med pa'i byang chub tu sems bskyed pa yan chad mos pas spyod pa'i sa la gnas pa rnams so). On the Profane and the production of the thought of awakening, see MSAVBh D3a4-5/P3b2.

96 According to Sthiramati's commentary to the ANS at MSAVBh D55a6-7/P65a6-7, the dharmālambanā karu$n \bar{a}$ characterizes the caryāpratipanna Bodhisattva, i.e., between the first and the seventh level inclusively. Some useful information is provided in Braarvig 1993: II.252, note 3.

${ }^{97}$ MSAVBh D56a4-5/P66a6-7: mi dmigs pa'i byams pas ni sems can dang chos kyi stong pa nyid la dmigs te / de'i tshe sems dang sems las byung ba'i tshogs rnams ci la yang mi rtog pa'i mtshan nyid du ro gcig par gnas pas sems can tha dad pa dang / chos tha dad pa byed pa med pas na mi dmigs pa'i byams pa zhes bya'o //. "The friendliness that has no object is directed toward the emptiness of living beings and of constituents(/of Dharma?). [That is to say:] at that time, the group of thoughts and mental factors (cittacaitta) - which have a unique flavour (ekarasa) in so far they have as their characteristic [the fact of] no longer imagining anything at all - no longer perceive distinct living beings and constituents. [We] therefore [say of this friendliness] that is is without [any] object." Some useful information is provided in Braarvig 1993: II.352, note 4 (mi skye ba'i chos la bzod pa ni sa brgyad pa yan chad la bya ste, de dag gi mtshan ma med pa la lhun gyis grub par 'jug pas de dag gi byams pa ...). See also MSA 17.18 $\mathrm{c}_{2} \mathrm{~d}_{1}$, together with MSABh 121,23-24 (Maithrimurthi 1999: 360), and MSAVBh D56a2-5/P66a3-7.

98 Viévard 2002: 275.

99 Viévard 2002: 276. This is also the opinion of Śākyabuddhi and Karṇakagomin at PVT Je D24b6-7/P29b3-4 = PVSVṬ 53,9-10: anālambanā grāhyagrāhakābhiniveśavigatānām buddhabodhisattvānām/. "[The immeasurables] of Buddhas and Bodhisattvas, who are free of [any] adherence to an object and a subject [of knowledge, are] without object."

100 Viévard 2002: 276.

${ }^{101} \mathrm{DBhS}$ (VII F) 58,7-10: yāni bodhisattvena prathamām bodhisattvabhūmim upādāya yāvat saptamī bodhisattvabhūmir ity adhinirhṛtāni jñānābhinirhāraprayogāñgāni imāny aștamīm bodhisattvabhūmim ārabhya yāvad atyantaparyavasānam ity anābhogena parinispadyante /. Translation by Viévard 2002: 276. Farther, the DBhS describes the Bodhisattva who has reached the eighth level as sarväbhogavigatah (VIII C, 64,15-16 and 25-26) and as anābhogadharmatāprāpta (VIII C, 64,16). The locus classicus of the distinction between sābhogatā and anābhogatā is found at DBhS (VIII K) 67,10-19: tad yathāpi nāma bho jinaputra mahāsamudragāmī poto 'prāpto mahāsamudram sābhogavāhano bhavati / sa eva samanantaram anuprāpto mahāsamudram anābhogavāhano vātamaṇ̣̂ī̄prañito yad ekadivasena mahāsamudre kramate tad sarvasābhogavāhanatayā na śakyạ̣ varṣaśatenāpi tāvad aprameyam anuprāptum / evam eva bho jinaputra bodhisattvah susam- 
réalisation du savoir (jũāna) produits par le Bodhisattva depuis la première Terre jusqu'à la septième Terre du Bodhisattva sont parfaitement achevés (pari-niṣ-PAD-) sans effort (anābhogena), de la huitième Terre jusqu'à la toute dernière." The great compassion henceforth driving the Bodhisattva is a compassion which has, so to speak, undergone a double revolution because the Bodhisattva acquiesces to the non-arising of dharmas, and because the intentional effort that until then directed compassion toward beings and dharmas has ceased:102 "[L]e Bodhisattva, percevant la masse des êtres précipitée dans les quatre grands courants, ayant l'intention de les faire traverser, s'appuie sur le grand effort (vyāyāma) et le désir (autsukya) pour le parfait éveil par le savoir omniscient. Étant parvenu à s'appuyer sur une grande énergie (mahāvīrya), il obtient, immédiatement après, la [huitième] Terre du Bodhisattva immobile (acalā) et devient libre de tout effort (sarvābhoga). Aucune des manières de se conduire [basées] sur la dualité ou les apparences ne lui arrivent plus." The actions characteristic of the Bodhisattva who has entered the eighth level stand out not only because of their spontaneity and unintentionality, but also because they are uninterrupted, i.e., because of their serial continuity: ${ }^{103}$ "In that [context], what is the Bodhisattvas' abode that is free of intention, effort, and any character [that can be perceptually apprehended]? The abode is [as follows:] it is the one that, due to the repeated cultivation (bhāvanābāhulya) of the previous characterless abode, is associated (anugata) with a path [henceforth] proceeding without intermission or interruption, strictly spontaneously (svarasena eva)."

Let us now return to compassion and examine Sthiramati's explanation on the anālambana maitri of the ANS: ${ }^{104}$ "[Finally,] we say of the friendliness of the Bodhisattvas who have ac-

bhṛtamahākuśalamūlasambhāro mahāyānasamudāgamābhirūụho mahābodhisattvacaryāsāgaram anuprāpto yad ekamuhūrtena jñānānābhogatayā sarvajñajñānenākramati tan na śakyam pūrvakena sābhogakarmañā kalpaśatasahasrenāpi tāvad aprameyam anuprāptum /. "[It is here,] O Jinaputra, as [it is] with the boat [that] is sailing to the open sea (mahāsamudra): until it has reached the open sea, sailing is difficult (sābhoga $\left.{ }^{\circ}\right)$. But as soon as it has reached the open sea, that same [boat], carried by the winds, sails without any difficulty. [In fact,] no [boat] that sails with difficulty could ever travel, be it in one hundred or even in an infinite number of years, the [distance] it will travel in the open sea in one day. It is likewise, O Jinaputra, for the Bodhisattva who is well provided with the collections [of merit and wisdom] constituting the bases of virtue, who reaches the great ocean that is the career of the Bodhisattva embarked on the Great Vehicle: [none] of the prior actions made with effort could [ever] cover in one hundred thousand or even in an infinite number of cosmic periods what he covers in a [single] instant with his omniscient knowledge, because that knowledge is spontaneous (anäbhoga)." The tenth abode (vihāra) of the Bodhisattva of the BoBh corresponds to the eighth level of the $\mathrm{DBhS}$; that abode is called anabhisamskāro 'nābhogamārgavāhano nirnimitto vihārah (BoBh D217,1819/W318,1-2, D239,4/W350,12), and is also characterized by obtention of the anutpattikadharmakșanti (BoBh D239,14/W351,13-14 and D239,22-23/W352,22-23).

102 DBhS (VIII C) 64,22-27: bodhisattvaś caturmahaughaprāptam sattvakāyam saṃjānāna uttaraṇābhiprāyah sarvajñajūānābhisambodhāya mahad vyāyāmautsukyam ārabhate sa mahāvīryārambhaprāptạ samanantaram anuprāpta imām acalām bodhisattvabhūmim sarvābhogavigato bhavato / tasya sarveña sarvam dvayasamudācāro vā nimittasamud̄̄āāro vā nābhāsībhavati /. Translation by Viévard 2002: 277.

${ }^{103}$ BoBh D219,27-220,2/W320,24-321,2: tatra katamo bodhisattvānām anabhisamskāro 'nābhogo nirnimitto vihārah / yas tasyaiva pūrvakasya nirnimittasya vihārasya bhāvanābāhulyāt svarasenaiva niśchidranirantaravāhimārgānugato vihārah /. See also Maithrimurthi's very useful summary of that condition (Maithrimurthi 1999: 267)

${ }^{104}$ MSAVBh D55a7-55b1/P65a7-8: mi skye ba'i chos la bzod pa rab tu thob pa'i byang chub sems dpa' rnams kyi byams pa ni dmigs pa med pa zhes gsungs te / rnam par mi rtog pa lhun gyis grub pas rtsol ba dang 'bad pa med par byams pa 'byung ba'i phyir ro //. See also MSABh 166,5 ad MSA 19.38 (Maithrimurthi 1999: 256, 
quired the conviction that dharmas [ultimately] have no arising that it is 'without object', since [that friendliness] arises intuitively (nirvikalpa), spontaneously (anābhogena), and without difficulty or effort." This is also the doctrine reported in the BBhSŚ, of which Lamotte offers the following summary: ${ }^{105}$ "Les Bodhisattva qui ont obtenu la conviction que les dharma ne naissent pas (anutpattikadharmakșāntipratilabdha) cultivent surtout la maitrī sans objet. Bien qu'elle ait un objet, l'élément fondamental (dharmadhātu), elle est comme les dharma de rétribution (vipākadharma), oeil, etc., dépourvue d'imagination (vikalpa), ne fait pas d'effort (prayoga) et fonctionne spontanément (svarasena pravartate). C'est pourquoi elle est appelée la grande maitrī sans objet (anālambana), associée au savoir de l'égalité (samatājñānasamprayukta)."

4.4. The ideological complex developed in the DBhS, the BBhSŚ, the BoBh, the ANS and the MSAVBh around the acala bhümih deserves our attention since on the one hand, PV 2 implicitly describes the career of the Bodhisattva up to the attainment of awakening and the concomitant perfection of teaching, while on the other, its doctrine is based, as we have seen, on the notion of a spontaneous and uninterrupted development of compassion. It is therefore worth asking if this ideological complex is truly echoed among Buddhist theorists of knowledge. To answer that question, let us quickly examine PV 2.198-199 and its commentaries: ${ }^{106}$

\begin{abstract}
It is not the case that there is no deliverance (nāmuktih) [from samsāra] since [in the absence of a cause], once former [karmic] formations have been exhausted[, i.e., once the projective force of the previous act is exhausted], there is no reconnection to a new (anya) [suffering]; those immaculate ones (anagha)[, however], whose [karmic] formations have not lost their potential, do remain [in samssāra] ${ }^{107}$ Now since [their] compassion is weak, ${ }^{108}$ [the Hearers and Buddhas-for-themselves] do not [consent], in order to remain (sthāpana) [in samsāra], to the great effort [characteristic of the Bodhisattva, and therefore do not stay in samsāra very long]; but those who are devoted to others (parādhina) do remain, [they] whose compassion is great.
\end{abstract}

According to Devendrabuddhi, the "immaculate ones" mentioned in PV 2.198 are, "for example, the Bodhisattvas." 109 Sákyabuddhi adds that among those, ${ }^{110}$ "the potential of the [former] action is not exhausted, since the result of all [their] provisions [of merit and knowledge] is unfixed nirvāna (apratișthitanirvānaphala)." Attaining apratișthitanirvāna is generally a characteristic of the Bodhisattva who reaches the seventh level: whereas his understanding (prajña) enables him to grasp the emptiness of samsāra, his compassion for the beings who are caught

note 142), and MSAVBh D80b2-3/P95b7-8 ad MSABh 131,17

105 Traité III.1251; see also Traité V.1708.

${ }^{106}$ PV 2.198-199: nāmuktịh pūrvasamskārakṣaye 'nyāpratisandhitaḥ / akșinnaśaktih saṃskāro yeșām tiṣthanti te 'naghāh // mandatvāt karuṇāyāś ca na yatnah sthāpane mahān / tị̦țanty eva parādhīnā yeșām tu mahatī krpā //.

${ }^{107}$ PVP D84b7/P97b2: de ltar na dus thams cad du gnas par 'gyur ro //. PVV 79,10-11: yāvad ākāśam tiṣthanty eva $/$.

108 PVV 79,11-12: karmaṇo niyatakālasthitikadehākṣepakatvān mandatvāt karuñāyāh ... Cf. PVP D85a3-4/ P97b7-8.

${ }^{109}$ PVP D84b7/P97b3: dper na byang chub sems dpa' rnams kyi lta bu'o //. PVV 79,10: samyaksambuddhāh.

${ }^{110}$ According to PVT Nye D131b2-3/P162a2-3: dper na byang chub sems dpa' rnams kyi lta bu'o zhes bya ba ni / byang chub sems dpa' rnams ni las kyi nus pa zad pa ma yin te / tshogs thams cad mi gnas pa'i mya ngan las 'das pa'i 'bras bu can nyid yin pa'i phyir ro //. 
in samsāra prevents him from entering into nirvāna. ${ }^{111}$ The great compassion (mahatī krpāa) characteristic of "those who are devoted to others" (PV 2.199) also suggests that Dharmakirti was making an allusion to the buddhological theme defined above, in which the eighth level marks the elevation of compassion to the level of great compassion. Devendrabuddhi is even more explicit: that great compassion belongs to those mahâsattvas whose highly developed love freely expresses itself; ${ }^{112}$ due to the former practice of compassion, which was itself preceded by the thought of awakening, great compassion proceeds spontaneously. ${ }^{113}$ Even though the acala bhümih is not mentioned explicitly by Devendrabuddhi, his description is most likely meant to refer to the compassion of the Bodhisattva who has entered the eighth level, that same level which marks, as we have seen, the disappearance of all intentional effort and the passage into anābhogatā.

\subsection{Let us recall Devendrabuddhi's suggestive introduction to PV 2.124:114}

At a given moment, when one has reached a distinctive practice (prayoga) of [mental qualities] such as compassion, [these qualities] no longer depend on a new practice to proceed, but [rather,] the acquisition of [each new] improvement proceeds without [any] effort.

I would conjecture that the moment to which Devendrabuddhi is referring here coincides with the Bodhisattva's access to the eighth level, the abode where his psycho-cognitive endeavor becomes spontaneous. From that point on, cultivation is said to proceed intuitively (nirvikalpena, MSABh) and without interruption (niśchidranirantaravāhin, BoBh). The description of the corresponding vihära found in the BoBh also clearly suggests that it proceeds without intentional effort (anäbhogena, BoBh, DBhS, MSAVBh), without difficulty or effort whatsoever (rtsol ba dang 'bad pa med par, MSAVBh), and spontaneously (svarasena eva, BoBh, $\mathrm{BBhSS}$ ). Now if my interpretation is correct, the subsequent set of arguments (PV 2.124$131 \mathrm{ab})$ would refer to the anālambanā karuñā described in Idealist sources. And Dharmakīrti's arguments as well as the terminology that he uses tend to confirm this. For he is here not content with simply fixing as a condition to compassion the need for a durable substratum (sthirāśraya), which as we have seen is characteristic of Bodhisattvas alone (\$2.7). For compassion to reach its utmost limit, it must also require no further practice/effort ${ }^{115}$ (abhyāsa/[pra $]$ yatna/*prayoga) to reaccess the last state attained through its cultivation: it must become nature

${ }^{111}$ See note 51 above.

${ }^{112}$ According to PVP D84a4-5/P98a1: gang dag sems can chen po rgyu med par mchog tu mnyes gshin pa, which can be reconstructed as follows: *yeșām mahāsattvānām akāranaparamavatsalānām (based on PVV 79,15: yeșām akāranavatsalānām).

${ }^{113}$ According to PVP D85a5/P98a1-2: byang chub kyi sems sngon du song ba can gyi brtse ba goms pa'i stobs kyis rang gi ngang gis 'jug pa'i brtse ba chen po ...

${ }^{114}$ For the Tibetan text, see note 26 above.

${ }^{115}$ I do not believe that the reference to effort (yatna) found at PV 2.125 weakens my hypothesis. Rather, I believe that Dharmakīrti keeps with this terminology because he wants to remain coherent: the explicit context of this passage is not the Mahāyāna doctrine, but his discussion with Kumārila. The effort to which he is here referring can easily be interpreted in terms of *(punah)prayoga ([yang] sbyor ba, PVP D53a2/P60a3 and D53a3/P60a4) and (moments of) abhyāsa (PVV 55,7-8). PV 2.130 (see below) by itself suffices to establish the equivalence between abhyāsa and (pra)yatna. Even though he has entered the eighth level, the Bodhisattva has not completed his mental cultivation (bhāvanā); it has simply become mechanical, automatic, spontaneous. 
(svabhāva), proceed spontaneously (svarasena, *anābhogena). But only among the (great) Bodhisattvas can compassion become nature, not among the lower categories of Buddhist saints who are aiming only for "individual" nirvāṇa.

\section{The role of karuñ $\bar{a}$ in the general structure of PV 2}

5.1. In the footsteps of Dignāga and (first and foremost) against the Mīmāmsā, the aim of PV 2 is to demonstrate that the Buddha has become and is similar to a means of valid cognition (pramānabhūta). To accomplish this demonstration, PV 2.1-33 first defines the nature of that authority. At PV 2.1-7, Dharmakirti presents (what the tradition will construe as) two (conceptually equivalent but terminologically alternative) definitions of a pramāna, or means of valid cognition. At PV 2.8-28, he goes on to refute the two alternative conceptions of a permanent pramāna: the first conception, that of the Mìmāmsaka, being of a Veda that has no beginning and no human/divine author, and the second, of an eternal God who revealed the Scriptures. Finally at PV 2.29-33, Dharmakīti defines his own notion of authority in salvational matters: that of a Buddha who is omniscient not in so far as he knows the totality of the knowable, but in so far as he knows the totality of the means to salvation. ${ }^{116}$

PV 2.34 begins Dharmakīrti's commentary on the property/epithet jagaddhitaișin; ${ }^{117}$ here commences, therefore, his analysis of compassion. Devendrabuddhi introduces PV 2.34ab with a question: ${ }^{118}$ "Let us accept [that the Buddha] is a pramāna of the type [which you just described]; but what is the sädhana on the basis of which this [pramāna] is said to be established?" To this question Dharmakīrti answers: ${ }^{119}$ "The sādhana [of that pramāna is] compassion, [and] it [results] from constant practice." Properly practiced, compassion is therefore the means to become an authority in salvational matters. At PV 2.34-131ab, Dharmakīti demonstrates how, since a virtually unlimited series of births is possible, the cultivation of compassion can grow to the point that it will form the essence of the mental series.

At PV 2.131cd-138, Dharmakīrti goes on to discuss, without any transition, the theme of the Bodhisattva as śâstr. The master devotes those verses to the first philosophical tribulations of the Bodhisattva as well as to the path to awakening. There he describes the rational discovery of the cause of suffering (the personalist wrong view, satkayadrști, etc.), the identification of the antidote to that cause (perception of insubstantiality, nairātmyadarśana, etc.), and the mental cultivation of that antidote ${ }^{120}$ up to the definitive eradication of the traces of passions (PV 2.137), in short, up to awakening and access to buddhahood/sugatatva. PV 2.131cd-136 thus highlight the Buddhist motif of (two among) the three prajñ̄as ([śrutamaȳi,] cintāmaȳ, bhāvanāmay $\bar{\imath}$.

\footnotetext{
116 On PV 2.1-7, see van Bijlert 1989: 115-168, Franco 1997: 45-66, Krasser 2001; on PV 2.8-16, see Krasser 2002: II.19-55; on PV 2.29-33, see Eltschinger 2001: 101-114.

117 See note 2 above.

118 PVP D16a3/P17a8-b1: tshad ma de 'dra ba nyid 'dod mod kyi / de'i sgrub par byed pa yang ci zhig yin / gang

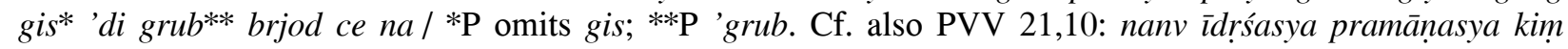
sādhanam ity $\bar{a} h a . .$.

119 PV 2.34ab ${ }_{1}$ : sāadhanam karuṇābhyāsāt sā ...

${ }^{120}$ On PV 2.131cd-142, see Eltschinger 2005a and 2005b: 175-179.
} 
5.2. Dharmakīrti's interpretation of the jagaddhitaiśin-śāstr sequence is however quite surprising. We cannot but be surprised to find that the Bodhisattva practices a compassion that is typical of the Mahāyāna even before having identified the salvational path and its twofold purpose (his own good, svārtha, which consists in being a Buddha/sugata, and the good of others, parārtha, which consists in being a teacher, śāstrtva). Moreover, traditional buddhologies profess that these mental qualities of karunā and prajñ $\bar{a}$ develop in parallel as one progresses through the levels. We can therefore wonder what might be the nature and intensity of the compassion of the Bodhisattva prior to his treading the path commended to him by his philosophical inquiry. In other words, what rhetorical status should we grant to PV 2.120-131ab, to those verses where, as we have seen, Dharmakīrti evokes the principle that compassion gradually becomes the intrinsic nature of the mental series? Are we presented with an argument in favour of a possibility that will only become a reality with practice and with the completion of the path (i.e., in parallel to the philosophical and cultivation processes described under the śāstr epithet), or rather a description the textual location of which would correspond to a "biographical" moment in the career of the (future) saint (i.e., before his identification and practice of the path)? In other words: in arguing that there is a direct causal relation between compassion and the Bodhisattva's rational discovery and practice of the path, is Dharmakīrti merely engaged in a rather servile elaboration on Dignāga's sequence, or does he rely on a narrative sequence that is both doctrinally and textually identifiable?

5.3. I am not in a position to discuss all the doctrines presenting compassion as a cause. One instance shall be sufficient. In many Mahāyāna śāstras and sūtras, compassion is considered to be the cause of bodhicittotpāda, the "production of the thought of awakening," a decisive event that marks the true beginning of a Bodhisattva's career. ${ }^{121}$ The BoBh identifies four causes (hetu) of the thought of awakening; among those, ${ }^{122}$ "compassion toward living beings is the third cause of the arising of [that] thought in the Bodhisattva." Earlier in the same chapter, the BoBh moreover states: ${ }^{123}$ "And that Bodhisattva, compassionate toward the suffering living beings, produces the thought of awakening, motivated by the intention to rescue [them]. The thought of awakening is consequently the outcome of compassion." Likewise, MSA 3.5 says that cittotpāda finds its root in compassion (karunāmūla), whereas in the DBhS it is said that ${ }^{124}$ "a thought for awakening arises in the Bodhisattvas who are turned to commiseration (krpā) and compassion." According to the same text, ${ }^{125}$ "that thought [of awakening] has great compassion for its precursor." Finally, let us follow Kamalaśîla in quoting the Daśadharmasūtra: ${ }^{126}$ "Having seen how living beings are without protection, without refuge [and] without shelter, [the Bodhisattva] develops a wish for compassion, [and this continues

${ }^{121}$ On bodhicittotpāda and concomitant themes (praṇidhāna, etc.), see Dayal 1978: 50-79.

${ }^{122}$ BoBh D10,11-14/W15,13-14: sattveșu kārunyam bodhisattvasya trtīyo hetuś cittasyotpattaye /. On the first two causes, see $\S 3$ above.

${ }^{123}$ BoBh D8,20-21/W13,5-7: duḥkhiteșu sattveṣu sa kāruṇiko bodhisattvah paritrānāahiprāyas tac cittam utpādayati / tasmāt sa cittotpādah karuṇāniṣyandah /.

124 DBhS (1 R) 11,13: kṛpākaruṇābhimukhānām (bodhi)sattvānām bodhāya cittam utpadyate /.

${ }^{125}$ DBhS (1 T) 11,20: [tac cittam] ... mahākarunāāūrvāingamam /.

${ }^{126}$ Quoted at BhK I.190,16-19: sattvān atrāṇān aśaraṇān advīpān dṛ̦țvā karuṇāyai cittam upasthāpya yāvad anuttarāyām samyaksambodhau cittam utpādayati /. See also Traité III.1711. 
through various stages] to the point of producing a thought for unsurpassed, perfect awakening." The causal sequence uniting compassion and the production of the (conventional) thought of awakening, or at least the resolution/vow (pranidhi, pranidhāna) which is part of it, certainly does occur in Dharmakīrti's own tradition. For example, Kamalaśīla makes several declarations to that effect in each of his three BhK's, of which the most significant for us goes as follows: ${ }^{127}$ "Therefore, for that [Bodhisattva], the promise (pratijñ $\bar{a}$ ) to save (abhyuddharana) all beings, [which proceeds] from the practice of commiseration, spontaneously (ayatnata eva) generates the thought of awakening, the aspect of which is to seek (prārthanā) unsurpassable, perfect awakening, as is said in the Daśadharmasütra."

In those Mahāyāna śāstras and sūtras, compassion precedes and generates the thought of awakening: it is the hetu, the müla, the pürvāingama, whereas the thought of awakening is the nisyandaphala. But in the BhK's, that causal sequence contributes to create a threefold schematisation of the path to awakening or omniscience: ${ }^{128}$ "To summarize, whoever wishes to quickly achieve omniscience must make an effort with regard to those three points: compassion, the thought of awakening and the (means of) realization (*sädhana)." In BhK I and II, Kamalaśîla borrows a similar passage from the Vairocanasambodhi(sūtra): ${ }^{129}$ "An omniscient person's knowledge has compassion for its root, the thought of awakening for its cause, and [salvational] means for its conclusion (paryavasāya)." In the BhK II, Kamalaśîla explains that passage as follows: ${ }^{130}$ "Therefore, those who wish to become omniscient must practice the three following [factors]: compassion, the thought of awakening and [salvational] means. Driven by compassion, the Bodhisattvas will necessarily take the vow to save all beings." That threefold structure finds a remarkable expression in BhK III: ${ }^{131}$ "Le Yogin, appuyé sur la moralité pure servant d'équipement au śamatha et à la vipaśyanā, produit envers les êtres une grande compassion; formant une résolution en vue de la Bodhi, il doit exercer l'audition, la réflexion et la méditation."

${ }^{127}$ BhK I.190,14-16: tasyaivam krpābhyāsabalāt sakalasattvābhyuddharaṇapratijñayānuttarasamyaksambhodhiprārthanākāram ayatnata eva bodhicittam utpadyate / yathoktạ̣ daśadharmasūtre /. See also BhK II, in the Tibetan text edited by Adam (2002: 185): des na rtsa ba'i snying rje goms par byas nas byang chub kyi sems bsgom par bya'o //. This could be reconstructed as follows: *ato mūlakaruñām bhāvayitvā bodhicittam bhāvayet /. "Therefore, having cultivated the compassion, which is [its] root, the thought of awakening must be cultivated."

${ }^{128}$ BhK I.229,15-17: thams cad mkhyen pa nyid myur du thob par 'dod pas mdor na snying rje dang / byang chub kyi sems dang / sgrub pa dang gnas 'di gsum la 'bad par bya'o //.

129 BhK I.196,20-21: tad etat sarvajñajñānam karuṇāmūlam bodhicittahetukam upāyaparyavasāyam /.

130 Tibetan text edited by Adam (2002: 180): de lta bas na thams cad mkhyen pa nyid thob par 'dod pas snying rje dang / byang chub kyi sems dang / thabs dang gsum po 'di dag la bslab par bya'o // snying rjes bskyod na byang chub sems dpa' rnams sems can thams cad mngon par gdon pa'i phyir nges par dam 'cha' bar 'gyur ro //. This could be reconstructed as follows: *tasmāt sarvajñatām adhigantukāmaih karunābodhicittopāyeșv eteṣu triṣu śikșitavyam / karuṇayā preryamāṇā bodhisattvāh sarvasattvābhyuddhāraṇārtham avaśyạ̣ pratijūāsyanti /.

${ }^{131}$ BhK III.3,6-8: tatra yoginā śilaviśuddhyādau śamathavipaśyanāsambhāre sthitena sarvasattveșu mahākarunā̄m utpādya, samutpāditabodhicittena śrutacintābhāvanāyām prayoktavyam/. Translated by Lamotte 1987: 338 (from the Tibetan!), without the Sanskrit reconstructions. 
5.4. Can the Mahāyāna sequence of compassion and the thought of awakening, as well as the threefold structure found in Kamalaśîla, serve as a clavis hermeneutica in our interpretation of PV 2? The initial and final terms of this threefold schema match with what we already know

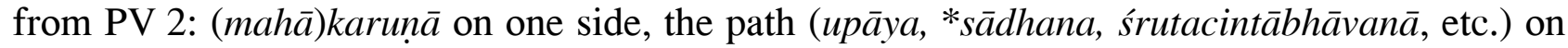
the other. What remains to be determined is if an allusion to the middle term, bodhicittotpāda, can be found in PV 2. To my knowledge, that important motif does not appear expressis verbis in the works of Dharmakirti. But PV 2.131cd-132ab would make a good candidate for a functional equivalent to bodhicittotpāda, situated as it is between the half-verse (PV 2.131ab) that ends the investigation of compassion and the half-verse (PV 2.132cd) that begins the investigation of the path and the prajñās. Let us consider those four pādas: ${ }^{132}$

[Wishing to calm other people's suffering,] the compassionate (dayāvat) [Bodhisattva] engages in [the cultivation of] means (upāya) to [calm suffering] in order to eradicate (hāna) [his own] suffering: [for] it is indeed a difficult task (duskara) for anyone to [correctly] teach [others about] the goal (upeya) and its cause [when they remain] imperceptible (parokșa).

Let us first remark that nothing in the direct commentaries suggests any allusion on the part of Dharmakīti to the production of the thought of awakening. According to Devendrabuddhi's commentary, ${ }^{133}$ the Bodhisattva's practice of compassion means that the Bodhisattva will suffer upon witnessing the suffering of others, and that he will consequently strive to calm that suffering. Compassion serves as the cause for the Bodhisattva's rational decision that he should himself directly realize ( $s \bar{a} k s \bar{a} t^{\circ} /$ pratyakșikarana) the path and its goal in order to teach them to those who are caught in painful transmigration and thus calm their suffering. That rational decision follows the maxim according to which we can only teach well what we know from experience. That undertaking is rational in so far as the quest for one's own good (svārtha $>$ sugatatva) is subordinate and becomes a means for insuring the good of others (parārtha >

${ }^{132}$ PV 2.131cd-132ab: dayāvān duhkhahānārtham upāyeṣv abhiyujyate // parokṣopeyataddhetos tadākhyānam hi duṣkaram / yuktyāgamābhyām vimṛsan duḥkhahetum parīkṣate //.

${ }^{133}$ PVP D54b2-7/P62a1-8: brtse ldan te / rgyu'i gnas skabs na yod pa'i ngang tshul can gyi brtse bas byang chub sems dpa' sems can gzhan gyi sdug bsngal gyis sdug bsngal bar gyur pa brtse ba la goms par gyur pas de dag gi sdug bsngal nye bar zhi bar don du gnyer ba can gyi sdug bsngal spang phyir de rab tu zhi ba'i thabs rnams la ni mngon sbyor mdzad / nyid nyid kyi sdug bsngal rab tu zhi ba dang rjes su mthun pa'i lam rtogs par byed pa zhes bya ba'i don to // ... nyid nyid kyi sdug bsngal rab tu zhi ba'i thabs rtsom pa gang yin pa 'di nyid gzhan gyi don dang rjes su mthun pa yin no // de lta yin na ... de'i rgyu gang yin pa nan tan du byas pa las de'i thabs las byung ba'i don de gdul bya de dag gis thob par 'gyur ro // ... lam mi shes pas phyin ci ma log pa'i lam ston pa'i skabs med pa'i phyir* re zhig rtogs pa dang ldan pa nyid sems can rnams la de nyid dang de'i rgyu ji ltar gnas pa bzhin $d u$ 'chad par bzhed pas mngon sum du mdzad pa yin no //. *Note Vibh. 57, note 2: na hy amārgajño 'viparītamārgopadeśe 'dhikriyate /. “[By] 'compassionate,' [Dharmakīrti means:] with compassion as a cause (*hetvavasthābhāvinyā dayayā); having practiced compassion, the Bodhisattva [himself] suffers from the pain [affecting] other beings (*parasattvaduhkhaduhkhita); seeking (prārth-, arthin) to calm (upaśama) their suffering, he himself engages in [the cultivation of] means to calm (praśama) that [suffering, first] in order to eliminate (hāna) [his own] suffering. The meaning [intended by Dharmakīrti] is that [the Bodhisattva will] practice (pratipad-) a path capable of calming his own suffering ... [In fact,] establishing the means of calming his own suffering is alone suitable to the good of others. In this way, by practicing (anușthāna) the [path] that [serves] as its cause ..., those [beings] who are to be instructed (vineya, vaineyaka) will reach the goal [associated] with that [means] (tadupeyārtha) ... [But] a [person] who does not know [himself] the path [to be followed] is not qualified to indicate the right path; therefore, [if he is] rational (prekșāvat), the [Bodhisattva] who wishes to teach properly the [path] and its end to others [will] first realize (pratyakșikaraṇa, sākșātkaraṇa) [them for himself].” 
tāyitva). In this rational decision I see a functional equivalent of bodhicittotpāda, adapted to the agenda of Dharmakīrti's school.

Moreover, I believe that I am not alone in interpreting those four $p \bar{a} d a$ s as a logico-epistemological variation on the Mahāyāna theme of bodhicittotpāda. In a segment of his long commentary to TS no. 3337(/8), Kamalaśîla brings together all the themes mentioned above: the notion of a rational choice, a quote of PV 2.132ab and the threefold division of karuna - bodhicitta - upāya found in the BhK's. Here is the passage in question: ${ }^{134}$

And neither could [our opponent] say the following: 'A [mental] cultivation that would result in a perceptual knowledge of the type [that you assert] is not possible for anyone.' [Our opponent could not say this] for he would [then] have to state the reason for [such] an impossibility. (...) Here, since the praxis of a rational [person always] implies usefulness, the reason for not engaging in [mental] cultivation could be that [the mental cultivation of insubstantiality] is useful to nobody whatsoever. (...) First, among the [various reasons supposed to justify the fact that a rational person does not engage in mental cultivation], uselessness is not established. Indeed, fear of samsāra is the reason (nimitta) why those who are limited to the awakening of the Hearers or [Buddhas-for-themselves] cultivate insubstantiality: [their] thoughts being tormented by the suffering of birth, etc., [their] mind being terrified by samsära, they seek to calm it for themselves. But since [a person] to whom the goal and its cause [remain] imperceptible cannot [properly] teach them [to others], the reason why the [Bodhisattvas] proceed with the cultivation is compassion: having by nature, due to a specific gotra, the good of others as their sole delectation, they consider [that] world afflicted by the three sufferings of being conditioned, etc.; and suffering from its painfulness because they rely upon commiseration, they reject [all] self-interest; and considering as themselves all the [beings] who are caught in transmigration, they make the vow to come to their rescue.

In this passage, Kamalaśîla attempts to demonstrate that the engagement in mental cultivation meets the conditions of rationality since it serves a purpose. Among the śāvakas and pratyekabuddhas, that purpose is none other than nirvanna "for oneself;" their motivation is the fear of painful transmigration. Among the Bodhisattvas, however, the motivation is compassion alone. Being awakened, the understanding that results from their mental cultivation will enable them to teach a path to peace of which they have a "personal" experience. In this way, compassion leads to the resolution to embrace the Bodhisattva career, i.e., it leads to the vow to implement the adequate means to awakening.

5.5. If my interpretation of these four pādas as a functional equivalent of bodhicittotpāda(/pranidhāna) is correct, Dharmakīrti's interpretation of the jagaddhitaișitvaśāstṛtva sequence is easily explained by means of a narrative micro-sequence common to Mahāyāna buddhologies: the practice of compassion precedes and generates the thought of awakening, which marks the beginning of the Bodhisattva's career as such. For Devendrabuddhi and Kamalaśila, the thought of awakening is a rational decision in which a series of means - śrutamay $\bar{\imath}$, cintāmay $\bar{\imath}$, bhāvanāmaȳ prajū $\bar{a}$, bodhi - are subordinated to the single goal of taking beings out of suf-

${ }^{134}$ TSP S1054,19-22 and 1055,14-20 ad TS no. 3337/K871,12-15 and 872,1-7 ad TS no. 3338: na cāpy evam śakyam vaktum - saiva tādṛ́ī bhāvanā na kasyacit sambhavati, yā tathābhūtapratyaksajñānaphalā bhaved iti, yato 'sambhave kāraṇam vacanīyam. tathā hi bhāvanāyām aprayoge sarveșām evānarthitvam ... kāranam bhavet, prekșāvatah pravrtter arthitayā vyāptatvāt. ... tatra na tāvad anarthitvam siddham. tathā hi ye tāvaj jātyādiduḥkhotpīẹitamānasāh samsārāad uttrastamanasas tadupaśamam ātmanah prārthayante, teșām șrāvakādibodhaniyatānām samsāīàd bhayam eva nairātmyabhāvanānimittam. ye tu gotraviśeșāt prakrtyaiva parahitakaranaikābhirāmāh samskārādiduhkhatātritayaparipīditam jagad avekșya, krpāparatantratayā tadduhkhaduḥkhinah svātmani vyapekșām apāsya, sakalān eva samsāriṇa ātmatvenābhyupagatās tatparitrāṇāya praṇidadhate, teșām karuṇaiva bhāvanāpravrttinimittam, parokṣopeyataddhetos tadākhyānasya duṣkaratvāt. 
fering existence. From an internal point of view, the Great Vehicle is the very expression of that rational decision; from an external point of view, it spells out the general context of that decision as well as its reason, its final goal and the means to its final goal.

We can therefore be sure that Dharmakīrti's causal interpretation, far from being imposed by the restrictive wording of the mangalaśloka, rests on a Mahāyāna narrative sequence that is clearly identifiable. Moreover, we can also determine without difficulty the meaning of PV 2.120-131ab: Dharmakirti there demonstrates the simple possibility of compassion becoming the intrinsic nature of the mental series, and not its actuality in a narrative/"biographical" sense. Though the practice of compassion starts at a quite early stage, its gradual and cumulative improvement can proceed only in conjunction with the development of prajñ $\bar{a}$, i.e., in narrative terms, in parallel with the path describing the Bodhisattva as śâstr. Likewise, its culmination will coincide with the definitive eradication of all traces of passions (kleśavāsanā, PV 2.137 and 141c) and of undefiled ignorance (akliștājñanna, cf. PV 2.141d). The Bodhisattva will ipso facto become a Buddha whose essence is composed of mental qualities such as compassion and insight (vipaśyanā, prajūāa), a Buddha superior to the śrâvakas and pratyekabuddhas. If, as Dharmakīrti and his epigones would have it, karunā is the cause or sādhana of the Buddha's authority, it is because it is the direct cause of bodhicittotpa $\overline{d a}$, which in turn is the cause of the career leading to awakening; the latter enables the new Buddha to teach the truths or the path with full authority (PV 2.145-146ab).

\section{Abbreviations}

Adam 2002

$\mathrm{AK}(\mathrm{Bh})$

ANS

BBhSŚ

Bendall/Rouse 1971

BhK I

BhK II

BhK III

BoBh

Braarvig 1993

BT

D

Dayal 1978

DBhS
See BhK II.

Abhidharmakośabhāṣyam of Vasubandhu, ed. P. Pradhan. Patna 1975.

Akșayamatinirdeśasūtra: Quoted from Śikṣ, Traité, etc. See Braarvig 1993.

Buddhabhūmisūtraśāstra: Quoted from Traité.

C. Bendall/W.H.D. Rouse, Śikșā Samuccaya, A Compendium of Buddhist Doctrine Compiled by Śāntideva, Chiefly from Earlier Mahāyāna Sūtras. Delhi 1971.

First Bhāvanākrama: G. Tucci, Minor Buddhist Texts. Delhi 1986, 497[/187]-529[/229].

Second Bhāvanākrama: M.T. Adam, Meditation and the Concept of Insight in Kamalaśila's Bhāvanākramas. Montreal 2002 (Unpublished PhD Thesis, McGill University, Faculty of Religious Studies), 178-229.

Third Bhāvanākrama: G. Tucci, Minor Buddhist Texts. Part III: Third Bhāvanākrama. Roma 1971.

$\mathrm{D}=$ Bodhisattvabhūmih [Being the XVth section of Asañgapāda's Yogācārabhūmih̀], ed. N. Dutt. Patna 1978. W = Bodhisattvabhūmi. A Statement of Whole Course of the Bodhisattva (Being Fifteenth Section of Yogācārabhūmi), ed. U. Wogihara. Tokyo 1971.

J. Braarvig, Akșayamatinirdeśa. Vol. 1: Edition of extant manuscripts with an index; vol. 2: The Tradition of Imperishability in Buddhist Thought. Oslo 1993.

Brhatṭīkā of Kumārila (lost, only in fragments).

sDe dge Tibetan Tripitaka bsTan 'gyur Preserved at the Faculty of Letters, University of Tokyo, ed. J. Takasaki, Z. Yamaguchi, Y. Ejima. Tokyo 1981 and following.

H. Dayal, The Bodhisattva Doctrine in Buddhist Sanskrit Literature. Delhi 1978.

Daśabhūmikasūtra et Bodhisattvabhūmi, Chapitres Vihāra et Bhūmi, ed. J. Rahder. Paris/Louvain 1926. 
Decourtemanche J.-A. Decourtemanche, Note sur l'ancien système métrique de l'Inde. Journal Asiatique, 1911 dixième série, XVIII (1911) 367-378.

Dunne 1996 J.D. Dunne, Thoughtless Buddha, Passionate Buddha. Journal of the American Academy of Religion LXIV/3 (1996) 525-556.

Eltschinger 2001 V. Eltschinger, Dharmakìrti sur les mantra et la perception du supra-sensible. Wien 2001.

Eltschinger

2005a

V. Eltschinger, Études sur la philosophie religieuse de Dharmakīrti: 1. Le Bouddha comme Śāstṛ et comme Sugata. Études Asiatiques/Asiatische Studien LIX/2 (2005) 395-442.

Eltschinger

$2005 b$

V. Eltschinger, Études sur la philosophie religieuse de Dharmakīrti: 2. L'āśrayaparivṛtti. Journal Asiatique 293/1 (2005) 151-211.

Franco 1997

E. Franco, Dharmakīrti on Compassion and Rebirth. Wien 1997.

Funayama 2000

Inami 1986

T. Funayama, Two notes on Dharmapāla and Dharmakīrti. Zinbun 35 (2000) 1-11.

M. Inami, Dharmakīti no jihi no shujyu ni giron (= Dharmakīrti’s Discussion on the Practice of Compassion). Indogaku Bukkyogaku Kenkyu 35/1 (1986) 137-141.

Iwata 2011 T. Iwata, Compassion in Buddhist Logic: Dharmakīrti's view of compassion as interpreted by Prajñākaragupta. In the present volume, pp. 211-230.

Kimura 1999 T. Kimura, A New Chronology of Dharmakīti. In: Dharmakīrti's Thought and Its Impact on Indian and Tibetan Philosophy. Proceedings of the Third International Dharmakirti Conference (Hiroshima, November 4-6, 1997), ed. S. Katsura. Wien 1999, 209-214.

Kośa L L Le La Vallée Poussin, L’Abhidharmakośa de Vasubandhu. Bruxelles 1980.

Krasser 2001 H. Krasser, On Dharmakīrti's Understanding of pramānabhüta and His Definition of pramāna. Wiener Zeitschrift für die Kunde Südasiens XLV (2001) 173-199.

Krasser 2002

La Vallée Pous$\sin 1907$

H. Krasser, Śañkaranandanas İśvarāpākaranasañkșepa. 2 vol. Wien 2002.

L. de La Vallée Poussin, Madhyamakāvatāra: Introduction au Traité du Milieu de 1'Ācārya Candrakīrti avec le commentaire de l'auteur, traduit d'après la version tibétaine. Le Muséon, nouvelle série, 8 (1907) 249-317.

Lamotte 1952 É. Lamotte, La bienveillance bouddhique. Bulletin de l'Académie Royale de Belgique (Classe des Lettres), 1952 (juillet) 381-403.

Lamotte 1987 É. Lamotte, Le troisième Bhāvanākrama de Kamalaśîla. Traduction de la version tibétaine. In : P. Demiéville, Le Concile de Lhasa. Une controverse sur le quiétisme entre bouddhistes de l'Inde et de la Chine au VIII siècle de l'ère chrétienne. Paris 1987, 336-353.

Maithrimurthi 1999

M. Maithrimurthi, Wohlwollen, Mitleid, Freude und Gleichmut. Eine ideengeschichtliche Untersuchung der vier apramānas in der buddhistischen Ethik und Spiritualität von den Anfängen bis hin zum frühen Yogācāra. Stuttgart 1999.

MAVṬ

MPPŚ

$\operatorname{MSA}(\mathrm{Bh})$

Sthiramati: Madhyāntavibhāgaț̄īā, exposition systématique du Yogācāravijāānavāda, ed. S. Yamaguchi. Nagoya 1934.

See Traité.

Asanga, Mahāyānasūtrālaṃkāra. Exposé de la Doctrine du Grand Véhicule selon le Système Yogācāra, ed. S. Lévi. Paris 1907. MSA(Bh) 17 was the object of two partial editions: (1)= Maithrimurthi 1999: 329-357 (MSA[Bh] 17.17-65); (2) see Nagao 2000 (MSA[Bh] 17.2964).

MSAṬ Mahāyānasūtrālañkārațīkā of *Asvabhāva: D no. 4029, Bi 38b6-174a7/P no. 5530, Bi 45a5$196 a 7$.

MSAVBh $\quad$ Mahāyānasūtrālankkāravrttibhāṣya of Sthiramati: D no. 4034, Mi 1-Tsi 266a7/P no. 5531, Mi $1-T$ si 308a8.

Nagao 2000 G.M. Nagao, The Bodhisattva's Compassion Described in the Mahāyānasūtrālaṃkāra. In: Wisdom, Compassion, and the Search for Understanding. The Buddhist Legacy of Gadjin M. Nagao, ed. J. Silk. Honolulu 2000, 1-38. 
P

Pagel 1995

PS(V)

PV 1

PV 2

PVA

PVP

PVSV

PVSVT

PVT

$\mathrm{PVT}_{\mathrm{R}}$

PVV

$\mathrm{R}$

Renou/Filliozat 1985

Seyfort Ruegg 1969

Śiks

Traité

TS(P)

van Bijlert 1989

Vibh.

Viévard 2002
The Tibetan Tripitaka: Peking Edition, ed. D.T. Suzuki. Tokyo/Kyoto 1957.

U. Pagel, The Bodhisattvapițaka. Its Doctrines, Practices and their Position in Mahāyāna Literature. Tring (U.K.) 1995.

Pramānasamuccaya(vrtti) of Dignāga.

Pramānavārttika, chapter 1 (Svārthānumānapariccheda): See PVSV.

Pramānavārttika, chapter 2 (Pramāṇasiddhipariccheda): Y. Miyasaka, PramāṇavārttikaKārikā (Sanskrit and Tibetan). Acta Indologica II (1972) 1-206. See also PVV.

Pramānavāarttikabhāsyam or Vārttikālañkārah of Prajñākaragupta (Being a Commentary on Dharmakīrti's Pramānavārttikam), ed. R. Sāṅkṛtyāyana. Patna 1953.

Pramānavārttikapañjikā of Devendrabuddhi: D no. 4217, Che 1-326b6/P no. 5717, Che 1$390 \mathrm{a} 8$.

Pramānavārttikasvavrtti: The Pramānavārttikam of Dharmakīrti. The First Chapter with the Autocommentary, ed. R. Gnoli. Roma 1960.

Ācārya-Dharmakīrteh Pramānavārttikam (Svārthānumānaparicchedah) Svopajñavrịttyā Karṇakagomiviracitayā tațtīkayā ca sahitam, ed. R. Sānkrtyāyana. Kyoto 1982 (Allahabad 1943).

Pramānavārttikațīkā of Śākyabuddhi: D no. 4220, Je 1-Nye 282a7/P no. 5718, Je 1-Nye $348 \mathrm{a} 8$.

Pramānavārttikațīka ad PV 2 of Ravigupta: D no. 4225, Pe 293b1-398a7/P no. 5726, Tshe 137a3-266a6.

Dharmakīrti's Pramānavārttika with Commentary by Manorathanandin, ed. R. Sāñkṛtyāyana. Journal of the Bhandarkar Oriental Research Institute 24-26 (1938-1940), Appendix.

Ratnakīrtinibandhāvalih, ed. A. Thakur. Patna 1975.

L. Renou/J. Filliozat: L'Inde classique: Manuel des études indiennes. 2 vol. Paris 1985.

D. Seyfort Ruegg, La théorie du Tathāgatagarbha et du Gotra. Études sur la Sotériologie et la Gnoséologie du Bouddhisme. Paris 1969.

Śikshāsamuccaya, A Compendium of Buddhist Doctrine Compiled by Śāntideva, Chiefly from Earlier Mahāyāna-Sūtras, ed. C. Bendall. Mouton \& Co - 'S-Gravenhage 1957.

É. Lamotte, Le Traité de la Grande Vertu de Sagesse de Nāgārjuna (Mahāprajñāāāramitāśāstra), vol. III and V. Louvain-la-Neuve 1970 and 1980.

$\mathrm{S}=$ Tattvasangraha of Ācārya Shāntarakșita with the Commentary 'Pañjikā' of Shri Kamalashīla, ed. Dvārikadās Śāstrī. Vārāṇasī 1982. K = Tattvasangraha of Śantarakṣita With the Commentary of Kamalaśila, ed. E. Krishnamācārya. Baroda 1988.

V.A. van Bijlert, Epistemology and Spiritual Authority. Wien 1989.

Notes of Vibhūticandra to PVV: See PVV.

L. Viévard, Vacuité (śūnyatā) et compassion (karuṇā) dans le bouddhisme madhyamaka. Paris 2002. 